Ruiz, J.C. (2020): "Elementos escultóricos del periodo romano conservados en el Museo Diocesano de Tarragona", Spal 29.2: 147-177. DOI: https://dx.doi.org/10.12795/spal.2020.i29.22

\title{
ELEMENTOS ESCULTÓRICOS DEL PERIODO ROMANO CONSERVADOS EN EL MUSEO DIOCESANO DE TARRAGONA
}

\section{ROMAN SCULPTURAL ELEMENTS IN THE DIOCESAN MUSEUM OF TARRAGONA}

\author{
JULIO C. RUIZ \\ Instituto Catalán de Arqueología Clásica (ICAC), Tarragona \\ Plaza d'en Rovellat, s/n, 43003 Tarragona \\ Correo-e: jcruiz@icac.cat (D) https://orcid.org/0000-0002-6562-9040 \\ Web of Science ResearcherID: https://publons.com/researcher/AAG-2008-2019
}

\begin{abstract}
Resumen: Este trabajo se ocupa de los elementos escultóricos romanos conservados en el Museo Diocesano de Tarragona. Una gran parte de ellos se encontraba inédita hasta la actualidad. En su práctica totalidad pertenecieron al programa arquitectónico y figurativo del templo al divus Augustus, lo que se ve corroborado por sus circunstancias de hallazgo. Sin embargo, los ejemplares cuya procedencia se conoce fueron encontrados verosímilmente en contexto secundario, asociados a talleres de reciclado de mármoles a partir del periodo tardoantiguo. La mayor parte de los ejemplares corresponden a relieves arquitectónicos. Predominan los clípeos de Júpiter Amón y Medusa, conservándose principalmente fragmentos de corona con decoración perimetral de diversos tipos, aunque también se encuentran dos fragmentos con máscaras de Medusa. Se conservan asimismo restos de relieves de diversas tipologías y escasos ejemplares de escultura exenta. Casi todos los ejemplares estudiados están realizados en un mismo mármol blanco de grano fino, probablemente procedente de Luni-Carrara. El estudio de todos estos elementos escultóricos nos permite aportar nuevos datos sobre los programas ornamentales y figurativos del área del templo al Divus Augustus en Tarraco. Palabras claves: relieves, Júpiter Amón, Medusa, candelabros, estatuas, foro provincial, templo al Divus Augustus.
\end{abstract}

\begin{abstract}
This paper aims to study the sculptural elements of the Roman period, mostly unpublished, preserved in the Diocesan Museum of Tarragona. Almost all of them belonged to the architectural and figurative program of the temple of divus Augustus, as can be corroborated by its finding circumstances. However, the pieces whose origin is known were found probably in secondary context, associated with marble recycling workshops from the Late-Antique period. Most of the pieces correspond to architectural reliefs. The clipei belonging to masks of Jupiter Ammon and Medusa predominate. Fragments of the perimeter decoration of various types are mainly preserved, although two fragments with Medusa masks are also found. We have also detected the remains of other reliefs of various typologies and few examples of exempt sculpture. Almost all of the pieces studied are made of the same fine-grained white marble, probably from Luni-Carrara. The study of all these sculptural elements allows us to provide new data on the ornamental and figurative programs in the area of the temple of Divus Augustus in Tarraco.
\end{abstract}

Keywords: reliefs, Jupiter Ammon, Medusa, candelabra, statues, provincial forum, temple of Divus Augustus. 


\section{INTRODUCCIÓN}

El Museo Diocesano de Tarragona (en adelante MDT) conserva un abundante número de obras de arte religioso, fundamentalmente de época medieval, procedentes de la catedral y la diócesis tarraconenses. Sin embargo, también cuenta entre sus fondos con un conjunto de materiales arqueológicos romanos que han ingresado en este museo debido a determinadas circunstancias. Entre ellos se encuentran fundamentalmente elementos arquitectónicos en mármol y otras materias primas lapídeas, pero también escultóricos, principalmente relieves, y algunas inscripciones latinas significativas. Algunas de estas piezas proceden de colecciones de particulares que, en algunos casos, las custodiaban por haber aparecido en solares del casco antiguo de Tarragona que eran de su propiedad. Sin embargo, la mayor parte de estos elementos arqueológicos proceden de la catedral y su entorno. Su principal interés radica en que forman parte del programa arquitectónico, figurativo y ornamental del área del templo al divus Augustus, que se ubicaba en la Antigüedad aproximadamente en el mismo lugar que en la actualidad ocupa la catedral (Macias et al. 2007, Macias et al. 2014, Mar et al. 2012: 348-374, Mar et al. 2015: 83129, Fishwick 2017: 135-183, Pensabene y Domingo 2019) (fig. 1a). Sobre la investigación arqueológica de este templo quedan aún numerosas cuestiones por resolver, como ponen de manifiesto las publicaciones que han salido a la luz últimamente (Peña 2018, Pensabene y Domingo 2019, Peña, en prensa).

No obstante, hay algunas cuestiones sobre las que existe un cierto consenso. Para empezar, es prácticamente unánime la relación de este edificio templar con la conocida cita de Tácito, según la cual una embajada de Hispani solicitó permiso al emperador para construir un templo en la colonia Tarraco, sirviendo como ejemplo para las restantes provincias (Tac., Ann. I, 78). La opinión mayoritaria sitúa esta embajada en torno al año 15 d.C. y lo reconoce como testimonio de la autorización de Tiberio para la construcción de un templo provincial al Divus Augustus en el Mediterráneo occidental, tratándose de la primera iniciativa para la institución de un ceremonial de culto imperial a nivel provincial (Alföldy 2002: 183-186). A su vez, este testimonio se ha puesto en relación con una serie de acuñaciones locales fechadas en el periodo tiberiano, que muestran en el anverso una figura entronizada con la leyenda DEO AVGVSTO y, en el reverso, la fachada de un templo octástilo acompañado de la leyenda AETERNITATIS AVGVSTAE C.V.T.T. (Villaronga y Benages 2011: 630, n. ${ }^{\circ} 3262 ; 631-632$, n. $^{\text {3 } 3267) . ~ E n ~ b a s e ~ a ~ t o d o ~ e l l o ~ s e ~ h a ~}$ propuesto una primera fase del edificio templar en el periodo julio-claudio, con la que han sido relacionados algunos elementos de decoración arquitectónica (Pensabene y Domingo 2019: 66-68). Entre estos elementos arquitectónicos destaca un capitel de pilastra que ha sido datado en época tiberiana (Pensabene 1993: 36-37, n. ${ }^{\circ}$, Domingo 2005: 178-179, n. $\left.{ }^{\circ} 14\right)$.

Sin embargo, esta fase julio-claudia es extremadamente problemática debido a la práctica inexistencia de elementos arqueológicos fechados en esta cronología. Esta parquedad de hallazgos puede explicarse teniendo en cuenta que, a partir de la época vespasianea, toda la parte superior de la ciudad fue remodelada para acometer la construcción de un nuevo complejo monumental de dimensiones gigantescas, conocido como "foro provincial" (Mar et al. 2015: 67-242, Pensabene y Domingo 2019). Su construcción conllevó una remoción de tierras que, en gran parte de la acrópolis, implicó rebajar el terreno hasta alcanzar la cota de la roca natural, acabando con toda evidencia asociada a periodos precedentes. Un proceso constructivo de tal envergadura ha de ponerse en relación necesariamente con la reforma del culto imperial acometida bajo el reinado de Vespasiano (Fishwick 2002: 3-16, 95-170). En Tarraco, se supone que esta reforma conllevó también una segunda fase constructiva del templo al divus Augustus, con la que se ha relacionado un fragmento epigráfico hallado en las últimas excavaciones en el entorno de la catedral que aparentemente menciona el edificio templar, denominado como templum divi Augusti (Peña et al. 2015). Por último, una cita de la Historia Augusta (H 12, 3-5) ha sido empleada para justificar la hipótesis de una reforma del templo por iniciativa de Adriano, en relación con su estancia en la ciudad en el invierno de 122-123 d.C. (Alföldy 2014). Con esta reforma han sido relacionados algunos elementos arquitectónicos en mármol de Proconeso, que han sido fechados en el periodo adrianeo, puesto que el empleo de este mármol en el Mediterráneo occidental se generalizó en el siglo II d.C. (Peña et al. 2015: 182, Pensabene y Mar 2019: 64.66.71.93).

La mayor parte de los elementos escultóricos que estudiamos en este trabajo enriquecen las evidencias conocidas del programa iconográfico del templo al Divus Augustus de Tarraco, del que ya nos era conocido un elevado elenco de testimonios (Koppel 1990: 332-339, lám. 32, Pensabene 1993: 80-87, n. ${ }^{\circ} 78-81$; 89-100, n. ${ }^{\circ} 85-100$, Pensabene y Mar 2004, Pensabene 2005, Macias et al. 2011, Goldbeck 2015: 88-93, figs. 124-130). Nuestro principal objetivo es realizar 


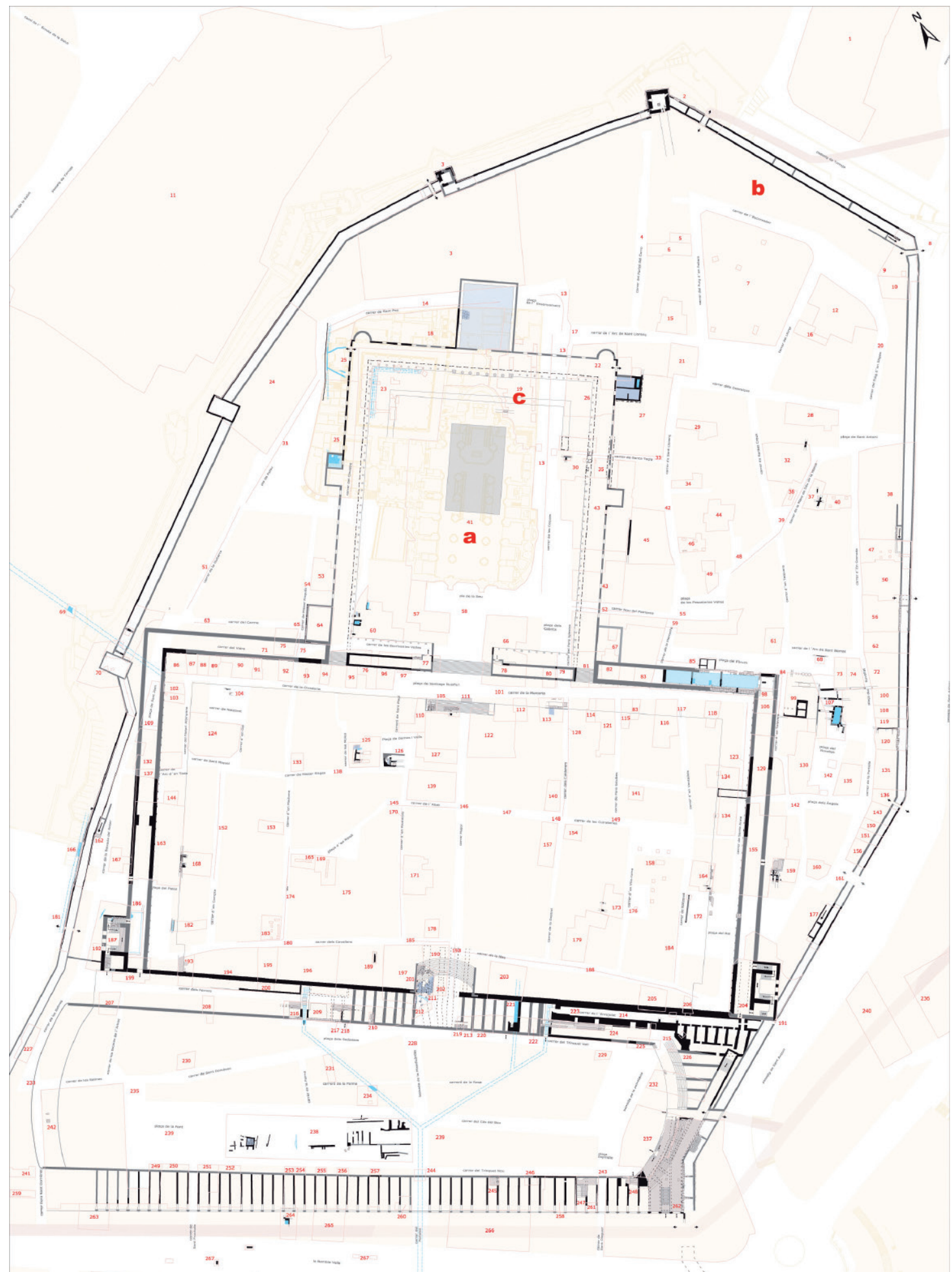

Figura 1. Planimetría del casco antiguo de Tarragona con los restos romanos del foro provincial, en relación a la trama urbana actual. Se indican asimismo los lugares mencionados en el texto. a: edificio de la catedral. b: Solar del antiguo edificio del matadero (Plaza de l'Escorxador, sin n. ${ }^{\circ}$ ). c: Jardín de Santa Tecla la Vella, parte excavada en 1933 (planimetría base de Macias et al. (dirs.) 2007: lám. A1). 
un estudio tipológico, iconográfico y estilístico de los materiales romanos en piedra que pueden ser considerados como elementos escultóricos, ya sea exentos o en relieve. Por lo que respecta a esta última categoría, no hemos incluido en nuestro estudio algunos materiales, que han sido anteriormente analizados por diversos autores que han resuelto las cuestiones sobre tipología, iconografía y estilo sin que podamos aportar datos especialmente novedosos o relevantes. Nos referimos principalmente a los sarcófagos, estudiados por M. Claveria, entre los que destaca el frontal con la escena de Apolo y las musas (n. ${ }^{\circ}$ inv. 3854; Claveria 2001: 29-30, n. ${ }^{\circ} 48$, lám. XX, 1), así como una caja cuyo frontal se decora con erotes sosteniendo guirnaldas que es una de las escasas piezas con motivos figurados en caliza local, en este caso llisós (n. ${ }^{\circ}$ inv. 268; Claveria 2001: 29, n. ${ }^{\circ} 47$, lám. XII, 1) y por último un fragmento de caja con motivo báquico (n. ${ }^{\circ}$ inv. 3591; Claveria 2001: 32-33, n. ${ }^{\circ}$ 55, lám. XXI, 1).. Esta misma autora incluyó asimismo otras cajas de sarcófago que no muestran ornamentación escultórica figurada (n. ${ }^{\circ}$ inv. 365.452; Claveria 2001: 3132, n. ${ }^{\circ}$ 52.53, láms. XX, 1 y XVII, 1). También hemos prescindido de la estela del auriga Eutyches (n. ${ }^{\circ}$ inv. D-150; CIL II $\left.{ }^{2} / 14.3,1281\right)$ y una crátera gallonada (n. ${ }^{\circ}$ inv. 480; $C I L \mathrm{II}^{2} / 14.3,1306$ ), para cuyos análisis pormenorizados remitimos al trabajo de G. Alföldy. Ambas han sido estudiadas por este autor desde el punto de vista epigráfico, si bien en las fichas correspondientes del $C I L \mathrm{II}^{2} / 14$ se recogen abundantes referencias bibliográficas anteriores entre las que se encuentran las que han tratado los motivos escultóricos. Asimismo, dedicaremos un estudio específico a otros tres relieves arquitectónicos, inéditos, que muestran únicamente motivos vegetales pero no presentan decoración figurada (Ruiz, en prensa).

Los materiales que estudiamos han sido muy escasamente atendidos en la investigación, pese a que se trata de testimonios significativos del programa figurativo y el repertorio ornamental del témenos del templo de culto imperial provincial. Tan solo habían sido objeto de una cierta atención los relieves arquitectónicos y más concretamente algunos fragmentos de clípeos, si bien de manera insuficiente, ya que carecen de un análisis exhaustivo. En su artículo sobre los clípeos con prótomos de las divinidades Júpiter Amón y Medusa, E. M. Koppel centra su atención en las partes figuradas de los conservados en el Museo Nacional Arqueológico de Tarragona (en adelante MNAT) y únicamente menciona de forma somera algunos del MDT en una nota al pie (Koppel 1990: 335, nota 42). De manera similar fueron tratados por P. Pensabene, en su artículo sobre los elementos de decoración arquitectónica atribuidos al área del templo; este autor incluye asimismo una parte de ellos en una única ficha que comprende piezas de tipologías diferentes y sin individualizarlas ni incluir ninguna fotografía (Pensabene 1993: 93-94, n. $\left.{ }^{\circ} 93\right)$. Únicamente habían sido atendidos en mayor medida por J. Gimeno en su tesis doctoral inédita (Gimeno 1990: 1280-1281, n. ${ }^{\circ} 1678-1680 ; 1283-1284$, n. $^{\circ}$ 1689-1690; 1285, n. ${ }^{\circ} 1695 ; 1289$, n. ${ }^{\circ} 1712$ ), si bien esta solo contiene fotografías de dos de ellos y la mayor parte ni siquiera están descritos, resultando incluso su clasificación en ocasiones poco acertada.

A todas estas circunstancias debemos añadir la necesaria tarea de revisión documental previa, que también hemos acometido en este trabajo, al constatar que en los trabajos mencionados existen diversas erratas al indicar los números de inventario, con frecuencia incluso omitidos, y otros datos como la procedencia. Además, cuando fueron vistas por Gimeno, Koppel y Pensabene las piezas se hallaban incrustadas en las paredes del antiguo museo, estando así hasta principios de los años noventa del siglo pasado, dificultando las valoraciones que podían realizarse sobre ellas. Por otra parte, también hemos detectado nuevos fragmentos de clípeos y otros materiales de diversa índole, que se encontraban totalmente inéditos hasta la publicación de este artículo.

Debido a todo ello se puede afirmar que estas piezas son prácticamente desconocidas en la bibliografía. Junto al análisis pormenorizado acompañado de fotografías de cada una de ellas, resulta particularmente interesante aportar datos precisos sobre la procedencia de estos materiales, puesto que hemos podido constatar que la mayoría de ellas fue recuperada en enclaves importantes del casco antiguo de la ciudad. Todo ello redunda en un mayor conocimiento no solo del programa figurativo del templo al divus Augustus, sino también del fenómeno de y reaprovechamiento de material marmóreo en la Antigüedad tardía y, en definitiva, en la transformación del paisaje urbano en el periodo postclásico. Hemos presentado todos los ejemplares en forma de catálogo razonado, con fichas individualizadas para cada uno de ellos (las dimensiones de los clípeos se expresan de manera radial, teniendo en cuenta la posición original del prótomo central). Este catálogo se organiza a su vez según el criterio de la procedencia de cada una de las piezas, dato clave para contextualizarlas y comprobar tanto sus lugares de exposición originales como sus dinámicas de reciclado en periodos posteriores. 


\section{LUGARES DE HALLAZGO DE LOS MATERIALES ROMANOS EN PIEDRA CONSERVADOS EN EL MDT}

Los autores que se han ocupado previamente de los materiales del MDT, especialmente en el caso de los elementos arquitectónicos, han afirmado que proceden de manera genérica de la zona de la catedral, en ocasiones dando por sentado que proceden del claustro (Gimeno 1990: passim, Pensabene 1993: passim, Pensabene y Domingo 2019: passim). Sin embargo, la consulta de documentación nos ha permitido conocer con mayor precisión los lugares donde fueron hallados numerosos materiales, en tanto que de una parte más escasa hemos podido confirmar que el único dato seguro es que proceden del entorno del edificio de la catedral. De este modo, las piezas fueron recuperadas mayoritariamente en excavaciones que, aun realizadas sin el rigor arqueológico necesario puesto que se llevaron a cabo con anterioridad al inicio de las prospecciones oficiales, o bien en intervenciones improvisadas, fueron llevadas a cabo en enclaves de gran relevancia en la topografía de Tarraco.

El museo fue inaugurado en $1914 \mathrm{y}$, en aquel momento, en lo referente a materiales de época romana, estaba constituido por piezas que se hallaban en el interior de la capilla de Santa Tecla la Vella, procedentes de puntos indeterminados de la catedral, como dos fragmentos de molduras (n. ${ }^{\circ}$ inv. 75: Gimeno 1990: 563-564, n. ${ }^{\circ}$ 549, Pensabene y Mar 2010: 272, fig. 16, Pensabene y Domingo 2019: 85 nota 268, fig. 38; n. ${ }^{\circ}$ inv. 257: Gimeno 1990: 580581, n. $^{\circ}$ 591). Sin embargo, entre los materiales arqueológicos que formaban parte de esta colección destaca numéricamente el conjunto donado por un particular de nombre Julià Delgado, integrado principalmente por elementos arquitectónicos (tab. 1), que habían sido hallados en 1898 durante las obras de construcción del antiguo edificio del matadero municipal, actual sede del Rectorado de la Universidad Rovira i Virgili en la Plaza de l'Escorxador, sin n. ${ }^{\circ}$ (fig. 1b). Asimismo, poco después de la inauguración del museo, en 1914/15 se enriqueció con donaciones de otros particulares destacando, por lo que respecta a elementos arqueológicos romanos, Ignasi Fortuny que, entre otros materiales, donó un fragmento de ropaje de una estatua (cat. n. ${ }^{\circ}$ 17); Antoni Pons, que en 1915 hizo lo propio con un fragmento de arquitrabe (n. ${ }^{\circ}$ inv. 1006; Gimeno 1990: n. ${ }^{\circ} 1728$ ); y Josep Maria Pujol, que donó un fragmento de capitel compuesto (n. ${ }^{\circ}$ inv. 786; Gimeno 1990: 1013, n. ${ }^{\circ} 1398$,
Pensabene 1993: 52-53, n. ${ }^{\circ}$ 27). Si bien no corresponde a un hallazgo escultórico, por su singularidad destaca un capitel realizado en biocalcarenita local que fue donado en 1915 por el Sr. Farré Durant y que, debido a sus características, se ha vinculado con los ejemplares del teatro, aunque al parecer fue hallado en el domicilio del donante, situado en el casco antiguo de Tarragona (n. ${ }^{\circ}$ inv. 1435; Gimeno 1990: 871-872, n. ${ }^{\circ} 1251$, Domingo 2005: 172-173, n. ${ }^{\circ} 11$, Domingo 2019: 82, n. ${ }^{\circ} 6$ ). Idéntica procedencia tiene un fragmento de cornisa en mármol blanco atribuido al área del templo al Divus Augustus (n. ${ }^{\circ}$ inv. 1436; Gimeno 1990: 564, n. ${ }^{\circ}$ 550).

A lo largo del siglo pasado el fondo de materiales de época romana se fue ampliando debido a diversas intervenciones arqueológicas. La más importante de ellas fue desarrollada en octubre de 1933 en el jardín situado frente a la capilla de Santa Tecla la Vella, donde el canónigo y arqueólogo Joan Serra Vilaró supervisó una excavación realizada en el punto situado delante de la cruz conmemorativa del IV Congreso Católico Nacional (Serra 1960: 81-82, fig. 27, Hauschild 1992: 110-111, fig. 6, Macias et al. -dirs.- 2007: 53, n. ${ }^{\circ}$ 19) (fig. 1c). En ella se documentaron piezas relevantes, bastante menos numerosas de las que salieron a la luz en 1898, pero algunas de ellas de mayores dimensiones y entidad (tab. 2). En el mismo jardín, muy cerca de este lugar, había sido recuperado en 1894 el sarcófago de L. Licinius Simmachus, anteriormente mencionado. Entre los elementos arquitectónicos hallados en 1933, por su singularidad destacamos dos molduras: la primera (n. ${ }^{\circ}$ inv. 3832 ) por estar reutilizada como pequeña pilastra y la segunda, de grandes dimensiones (n. ${ }^{\circ}$ inv. 3833; Gimeno 1990: 568, n. ${ }^{\circ}$ 561), por estar elaborada en pavonazzetto, lo que la diferencia del resto de elementos arquitectónicos en mármol, labrados generalmente en Luni-Carrara. Debido a la tonalidad amarillenta podría confundirse con la variedad del giallo antico, pero una observación atenta nos ha permitido corroborar su procedencia microasiática.

La mayoría de los restantes elementos marmóreos romanos conservados en el MDT, entre los que se encuentran básicamente elementos arquitectónicos, procede de otras intervenciones arqueológicas. En 1915, durante unas obras en una casa de la calle de la Destral, si bien el solar exacto se desconoce, se halló un elemento curvado en mármol que se ha atribuido a una cornisa o una moldura (n. ${ }^{\circ}$ inv. 1370; Gimeno 1990: 562-563, n. ${ }^{\circ}$ 548. Pensabene y Domingo 2019: 84, fig. 36). En 1979 se hallaron varios elementos romanos en el transcurso de la construcción del sepulcro del 
Tabla 1. Principales elementos arquitectónicos hallados en 1898 en el solar del antiguo edificio del matadero.

\begin{tabular}{|c|c|c|}
\hline Tipología pieza & N. ${ }^{\circ}$ inv. & Bibliografía \\
\hline $\begin{array}{l}\text { Fragmentos de capiteles } \\
\text { corintios (de columna, } \\
\text { pilastra y lesena) }\end{array}$ & $\begin{array}{l}562,564,568,578- \\
580,582\end{array}$ & 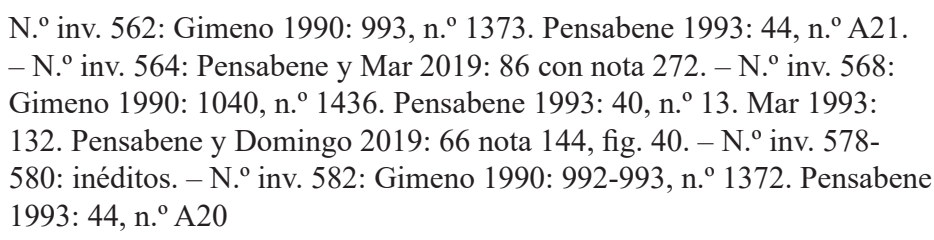 \\
\hline $\begin{array}{l}\text { Fragmentos de capiteles } \\
\text { compuestos (volutas) }\end{array}$ & 565,569 & 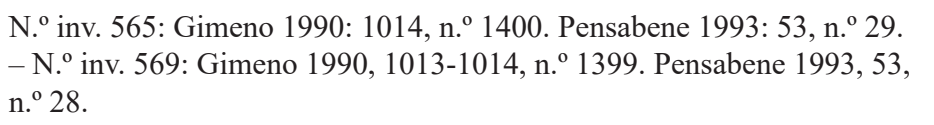 \\
\hline Fuste de pilastra & 650 & Inédito \\
\hline Fragmentos de arquitrabes & $\begin{array}{l}574,588,591,593 \\
596,597,602,603 \\
606,609\end{array}$ & 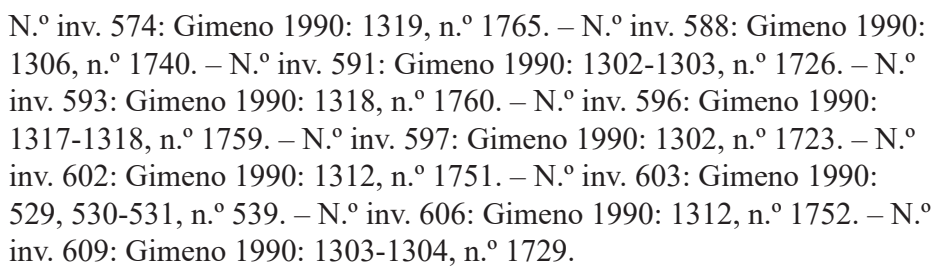 \\
\hline Cornisas & $\begin{array}{l}585,587,601,605 \\
614,615,639\end{array}$ & 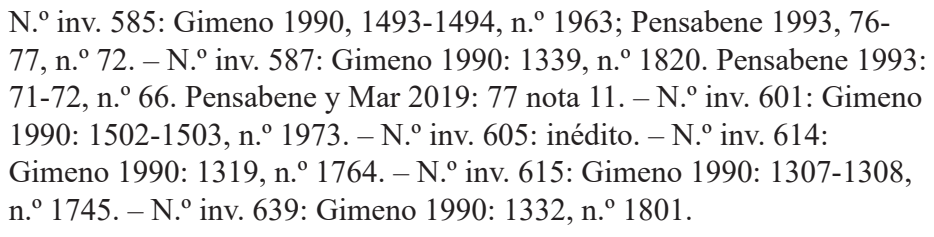 \\
\hline $\begin{array}{l}\text { Molduras de } \\
\text { coronamiento (¿cornisas?) }\end{array}$ & $\begin{array}{l}586,595,600,620 \\
625,6247\end{array}$ & 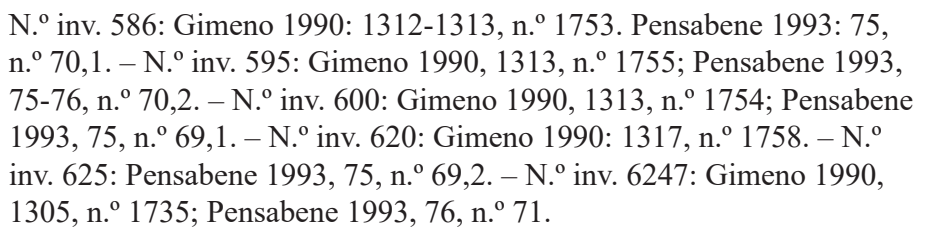 \\
\hline Molduras simples & $634,640,647$ & $\begin{array}{l}\text { N. }{ }^{\circ} \text { inv. 634: Koppel 1990: } 335 \text {, nota } 42 . \text { Pensabene } 1993: 93-94, \text { n. }^{\circ} \\
93 \text { (considerada erróneamente por estos autores como fragmento de un } \\
\text { clípeo). - N. } .^{\circ} \text { inv. 640: Gimeno 1990: } 564-565 \text { n. }^{\circ} 551 .- \text { N. }^{\circ} \text { inv. } 647 \text { : } \\
\text { Gimeno 1990: 582, n. }{ }^{\circ} 596 .\end{array}$ \\
\hline
\end{tabular}

cardenal Vidal i Barraquer, en el subsuelo de la capilla de San Fructuoso de la catedral. Entre ellos se encuentran algunos fragmentos de tambores de fustes de columna, que son de los pocos realizados en biocalcarenita encontrados en la catedral (n. ${ }^{\circ}$ inv. 5446.5447; Gimeno 1990: 276-277, n. ${ }^{\circ}$ 281; 317, n. ${ }^{\circ} 335$. Macias et al. 2007: 773, fig. 5,3.4). Más reciente ha sido el ingreso del fragmento de un fuste de columna acanalado, recuperado en 2004 (n. ${ }^{\circ}$ inv. 6245; Pensabene y Domingo 2019: 76-77 con nota 208).

\section{CATÁLOGO DE ELEMENTOS ESCULTÓRICOS}

\subsection{Solar del antiguo matadero, actual Rectorado de la Universitat Rovira i Virgili (1898) (fig. 1b)}

1. Fragmento de la zarpa de un felino (fig. 2)

N. ${ }^{\circ}$ inv. 5519. Mármol blanco, posiblemente de Luni-Carrara. Altura total conservada: $14 \mathrm{~cm}$; anchura: $11.5 \mathrm{~cm}$; 
Tabla 2. Elementos arquitectónicos hallados en 1933 durante la excavación del jardín de Santa Tecla la Vella.

\begin{tabular}{|c|c|c|}
\hline Tipología pieza & N. ${ }^{\circ}$ inv. & Bibliografía \\
\hline $\begin{array}{l}\text { Fragmentos de capiteles } \\
\text { corintios }\end{array}$ & $3384,3386,3821$. & $\begin{array}{l}\text { N.o inv. 3384: Gimeno 1990: 991-992, n. }{ }^{\circ} \text { 1370. Pensabene 1993: 39, } \\
\text { n. }{ }^{\circ} \text { 11. Mar 1993: 132, fig. 16. Domingo 2005: 42, fig. 7; 196, n. } 23 . \\
\text { Pensabene y Mar 2010: 266-267, fig. 14. Pensabene y Domingo 2019: } 66 \\
\text { nota 143, fig. 12. - N. } .^{\circ} \text { inv. 3386: Serra 1960: 82, fig. 27. Gimeno 1990: } \\
\text { 1028, n. }{ }^{\circ} \text { 1420. Pensabene 1993: 39-40, n. }{ }^{\circ} \text { 12. Mar 1993: 132, fig. } 16 . \\
\text { Pensabene y Mar 2010: 266-267, fig. 14. Pensabene y Domingo 2019: } 66 \\
\text { nota 145, fig. 13. - N. } .^{\circ} \text { inv. 3821. Inédito. }\end{array}$ \\
\hline Ábaco de un capitel & 6239 & Inédito \\
\hline Basa de pequeña columna & 3819 & Domingo et al. 2019, 114, n. ${ }^{\circ} 31$, fig. 5. \\
\hline $\begin{array}{l}\text { Fragmento de fuste } \\
\text { contraacanalado de } \\
\text { columna }\end{array}$ & 3820 & $\begin{array}{l}\text { Serra 1960: 82, fig. 27. TED'A 1989: 163-164. Gimeno 1990: 283-284, } \\
\text { n. }^{\circ} \text { 290. Pensabene 1993: 64-65, n. }{ }^{\circ} 49 .\end{array}$ \\
\hline Fragmentos de cornisas & 3363,3383 & $\begin{array}{l}\text { N. } .^{\circ} \text { inv. 3363: Pensabene 1993: 71, n. }{ }^{\circ} \text { 65. Pensabene y Domingo } 2019 \text { : } \\
77 \text { nota 211, fig. } 26 .- \text { N. }{ }^{\circ} \text { inv. 3383: Gimeno 1990: 1317, n. }{ }^{\circ} 1757 .\end{array}$ \\
\hline Arquitrabe & 3375 & Gimeno 1990: 529-530, n. ${ }^{\circ} 538$. \\
\hline Molduras & 3832,3833 & N.o inv. 3832: Inédito. - N. ${ }^{\circ}$ inv. 3833: Gimeno 1990,568, n. $^{\circ} 561$. \\
\hline
\end{tabular}
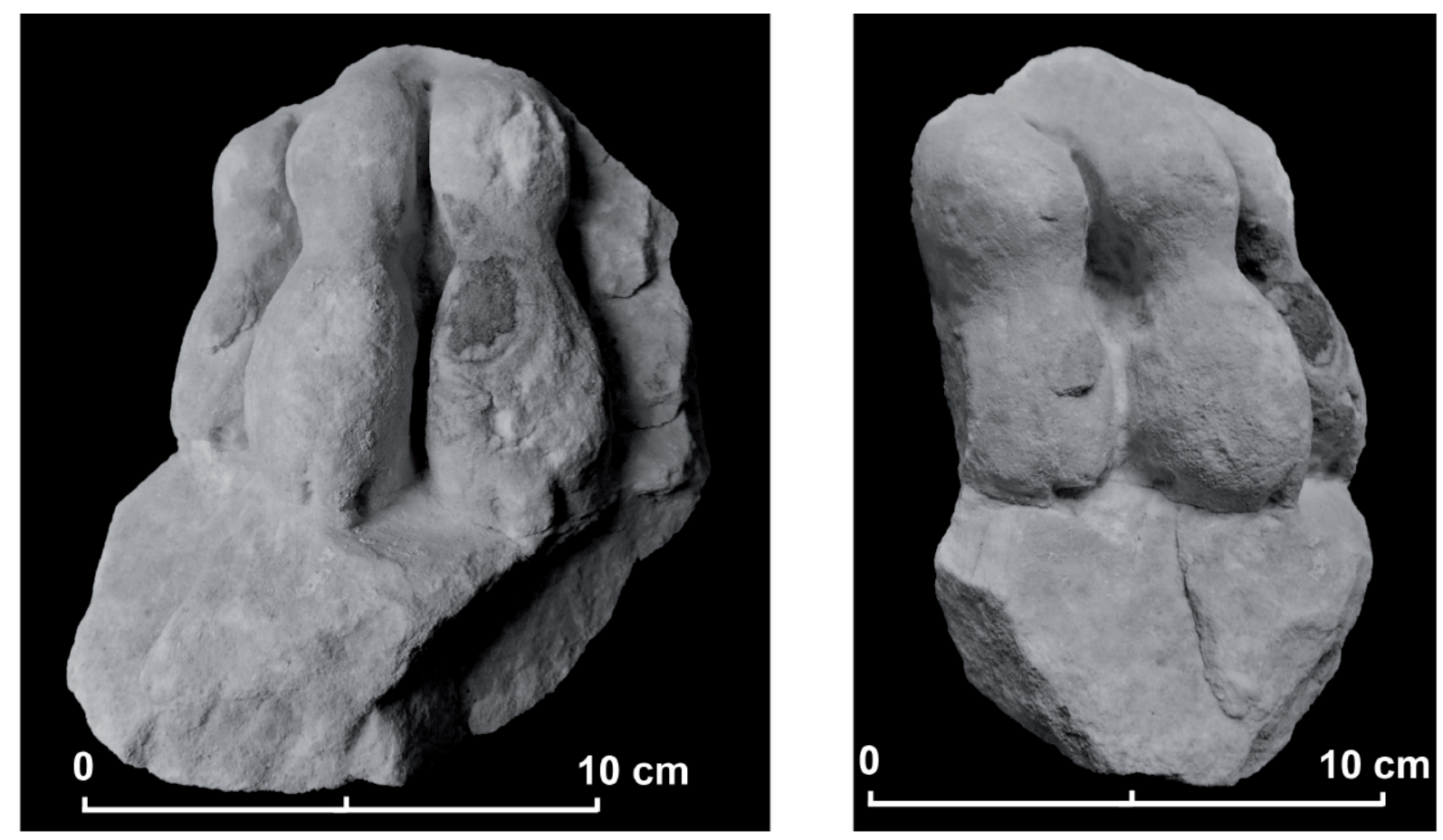

Figura 2. MDT, n. ${ }^{\circ}$ inv. 5519. Fragmento de la zarpa de un felino, probablemente perteneciente a una escultura decorativa.

profundidad: $11 \mathrm{~cm}$ - Altura conservada de la zarpa: $9.5 \mathrm{~cm}$; altura del plinto: $4.5 \mathrm{~cm}$.

La pieza, de la que nos ha llegado únicamente la parte anterior, está muy deteriorada y muestra numerosos desperfectos. La garra del extremo derecho está rota. Sobre una de las garras hay una gran mancha de óxido que, con bastante seguridad, se debe al contacto con un elemento metálico durante su proceso postdeposicional. 
Inédito

Parte anterior de la zarpa de un felino, posiblemente un león, que se asienta sobre una base de superficie superior lisa. Las garras están separadas entre sí por surcos relativamente finos, más profundos en la parte central, para los cuales se ha utilizado el trépano. Pese al deterioro, todavía se puede apreciar el límite anterior de la base en la que se apoya la zarpa, trabajado únicamente por medio del puntero, al igual que su parte inferior. Asimismo, en el lateral izquierdo de la base, desde el punto de vista del espectador, queda aún un exiguo resto del límite de la pieza en ese lado.

El estado tan mutilado de este ejemplar impide una datación precisa, así como concretar con seguridad el tipo de pieza al que perteneció. Se conocen numerosos ejemplares en los que, como en este caso, se ha conservado únicamente la zarpa y que plantean una problemática similar. Algunas piezas semejantes, como un ejemplar de Fréjus que conserva asimismo tan solo la zarpa (Lemoine 2013: 76 , n. $^{\circ} 155$, lám. 97), se consideran como soportes de objetos marmóreos decorativos, siendo interpretados preferentemente como patas de mesa. En cambio, otras muy similares y que se asientan sobre una base parecida se han supuesto como pertenecientes a figuras de bulto redondo. A modo de ejemplo, en un ejemplar de Vienne (Jockey 2003: 199, n. . 490, lám. 266) que muestra una zarpa asentada en una base de forma y dimensiones similares, se ha querido ver la pata de un águila perteneciente a un grupo estatuario junto con una imagen de Júpiter. Sin embargo, nos interesa destacar dos de Villa Adriana, semejantes entre sí, pero estudiados por autores diferentes que los han clasificado como piezas distintas: la primera se ha incluido en la categoría de plástica ideal (León y Vargas 2018: 115, n. ${ }^{\circ}$ 112) y la segunda se ha considerado como una pieza ornamental (Nogales 2018: 204, n. ${ }^{\circ}$ 206). Este caso ejemplifica a la perfección la problemática que plantea la pieza del MDT.

No se puede excluir totalmente que el fragmento perteneciese a una escultura exenta, en cuyo caso pudo haber representado a un felino de manera aislada o, posiblemente, que el animal acompañase a una figura mitológica dentro de un grupo escultórico. En este caso la imagen debería ser de tamaño mayor que el natural. Más probable nos parece que perteneciese a un objeto ornamental con decoración figurada, apoyado en un soporte con motivos felinos. Este motivo es frecuente especialmente en patas de mesa de diversos tipos (Cohon 1984: passim, Moss 1989: passim), pero también se constata en soportes de candelabros (Cain 1985: passim) y en objetos de diversa índole como p.ej. vascas o labra (ejemplar en el Museo Nazionale Romano: Paris 1979: 255-257, n. ${ }^{\circ}$ 159, Bonanome 2013). De ser esta la opción correcta, se trataría de un elemento indeterminado de mobiliario decorativo. Por su procedencia de un contexto similar resulta de interés la comparación con un conjunto hallado en el teatro romano de Vienne, integrado por varios soportes que se decoran en uno de sus lados cortos con una pata de felino (Hermary y Lauxerois 2003: 188-190, n. ${ }^{\circ}$ 450-457, láms. 257-258), siendo la zarpa leonina de uno de ellos muy similar a la del fragmento del MDT (Hermary y Lauxerois 2003: 189-190, n. ${ }^{\circ} 455$, lám. 258).

2. Fragmento de la corona de un clípeo decorada con meandros (fig. 3)

N. ${ }^{\circ}$ inv. 573-1. Mármol lunense. Longitud: $35 \mathrm{~cm}$; anchura: $25 \mathrm{~cm}$; profundidad: 9/15 cm.

Está fracturado por todos sus lados. Los rebordes de los meandros están rotos y los motivos en relieve tienen graves deterioros.

Gimeno 1990: 1280, n. ${ }^{\circ} 1678$ (con foto), Pensabene 1993: 93-94, n. ${ }^{\circ} 93$.

Fragmento de la corona de un clípeo decorado con meandros y flores de lis, que comprende asimismo una parte de la hilera de perlas que enmarcaba la máscara central, seguramente de Júpiter Amón, de la que no se conserva ningún vestigio. El contorno de los bastoncillos está claramente delimitado mediante surcos realizados con el trépano. El dorso muestra una superficie lisa que se ve interrumpida por una franja recta, cuya anchura se va prolongando en dirección al exterior del clípeo, que ha sido cortada con sierra. Esta particularidad se ha podido detectar en otro ejemplar del MDT (cat. n. ${ }^{\circ} 13$ ).

\section{Fragmento de la corona de un clípeo decorada con meandros (fig. 4)}

N. ${ }^{o}$ inv. 575. Mármol lunense. Altura: $26 \mathrm{~cm}$; anchura: $21.5 \mathrm{~cm}$; profundidad: $3 / 12.5 \mathrm{~cm}$.

La pieza está rota por todos sus lados. En la parte posterior gran parte de la superficie del mármol se ha desprendido. Los motivos esculpidos tienen graves deterioros y desperfectos de diversa índole.

Gimeno 1990: 1280-1281, n. ${ }^{\circ} 1679$.

Fragmento de la parte central de la corona de un clípeo, decorado con meandros y caulículos de los que surgen flores de lis. Como observó Gimeno, el caulículo que se conserva, correspondiente a un meandro 

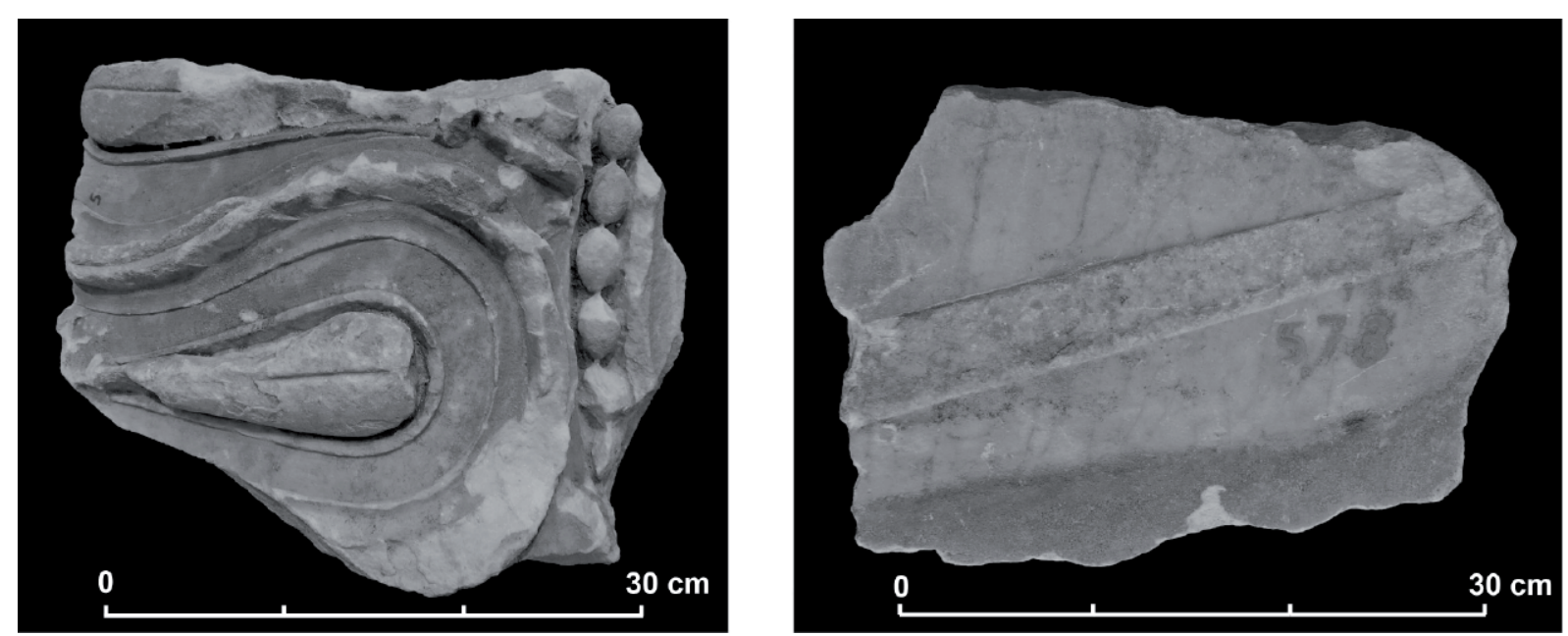

Figura 3. MDT, n. ${ }^{\circ}$ inv. 573-1. Fragmento de la corona de un clípeo decorada con meandros.
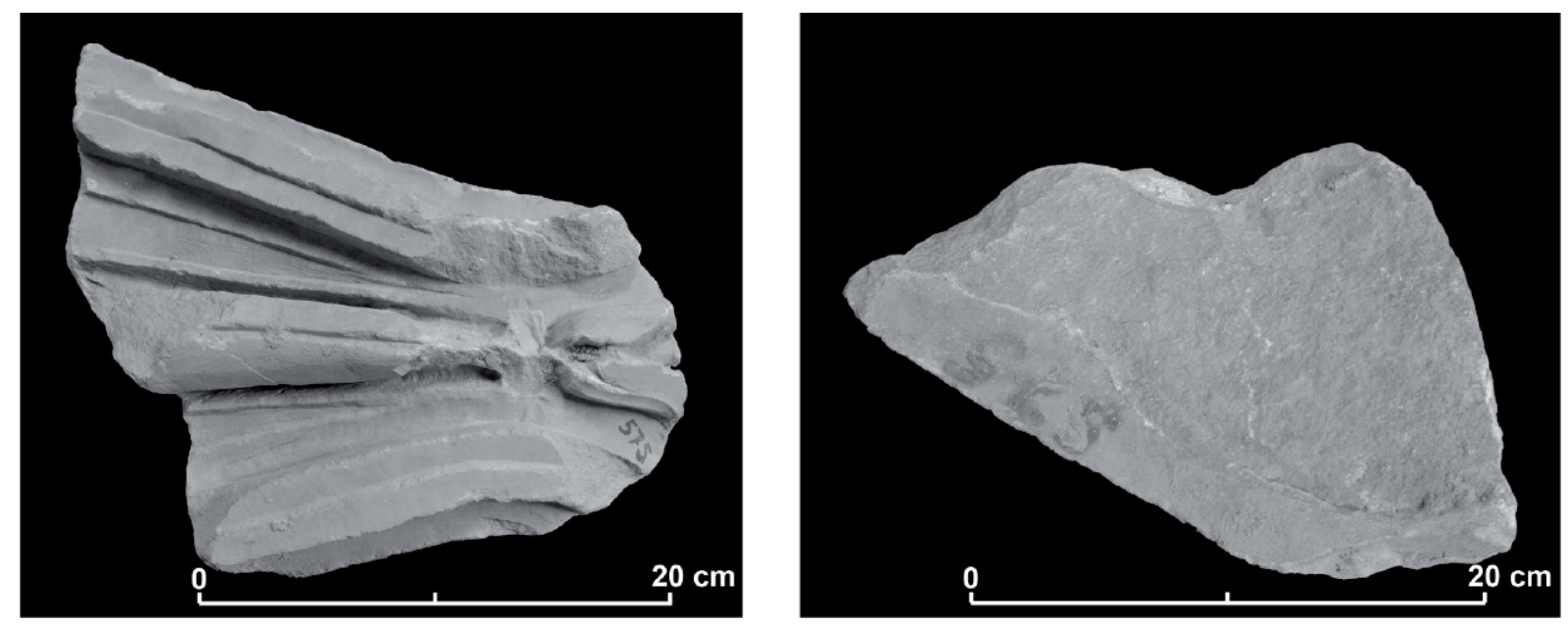

Figura 4. MDT, n. ${ }^{\circ}$ inv. 575. Fragmento de la corona de un clípeo decorada con meandros.

orientado hacia la parte interior del clípeo, parece más estilizado en comparación con las restantes piezas conocidas de clípeos decorados con meandros, por lo que probablemente perteneciese a una variante del motivo.

En el dorso, pese a su deterioro, conserva una pequeña franja de la superficie plana y alisada. Uno de los laterales está recortado intencionalmente siguiendo el contorno del meandro adyacente, lo que evidencia su reutilización.

4. Fragmento de la corona de un clípeo decorado con meandros (fig. 5)

N. ${ }^{\circ}$ inv. 573-2. Mármol lunense. Altura conservada: 13.5; anchura conservada: $15.5 \mathrm{~cm}$; profundidad conservada: $13 \mathrm{~cm}$.
Se conserva únicamente la parte anterior de la corona de un clípeo, roto por todos sus lados. La parte posterior está fracturada. Presenta graves deterioros en la base y el contorno del bastón, y leves en los rebordes del meandro.

Gimeno 1990: 1281, n. ${ }^{\circ} 1680$ (?), Koppel 1990: 335, nota 42, Pensabene 1993: 93-94, n. ${ }^{\circ} 93$.

Fragmento de la corona de un clípeo decorada con meandros. Nos ha llegado únicamente la parte más ancha de un meandro en cuyo lado se puede ver el pétalo derecho de una flor de lis adyacente. El trozo conservado corresponde a la zona más gruesa del clípeo, justo al lado de la máscara central rodeada por la hilera de perlas, de la que no queda ningún vestigio. Sin embargo, aún se puede observar el contorno redondeado, con una superficie relativamente irregular pero 

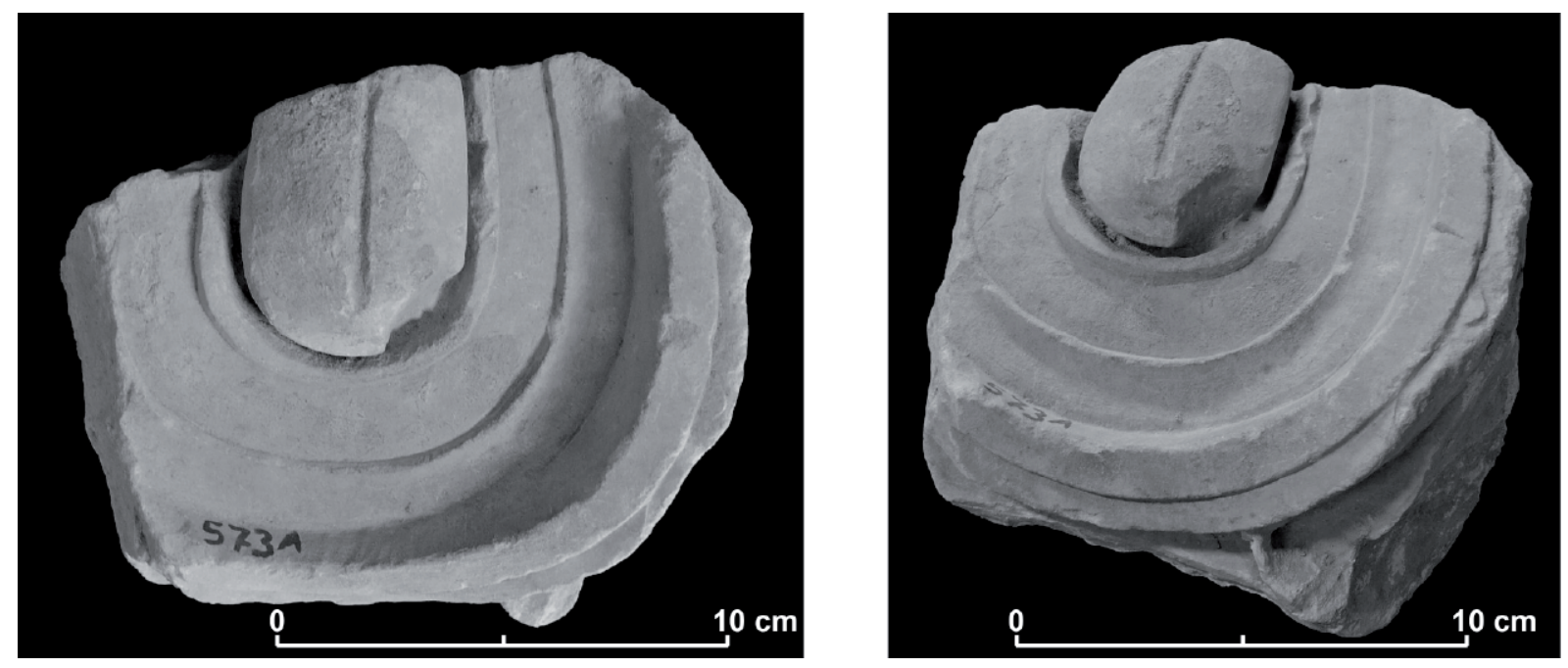

Figura 5. MDT, n. ${ }^{\circ}$ inv. 573-2. Fragmento de la corona de un clípeo decorada con meandros.

continua, donde se conservan los toques realizados sistemáticamente con una herramienta. Estos son similares a los que deja el punzón, lo que evidencia que la máscara fue arrancada intencionalmente.

\section{Fragmento de la corona de un clípeo} con lengüetas rectilíneas (fig. 6)

N. ${ }^{\circ}$ inv. 632. Mármol lunense. Altura: $26 \mathrm{~cm}$; anchura: $30 \mathrm{~cm}$; profundidad: $11 / 12.5 \mathrm{~cm}$.

Está roto por todos lados salvo en la parte superior, donde conserva la superficie plana y alisada original. Tiene deterioros graves en las caras anterior y posterior.

Koppel 1990: 335, nota 42, Pensabene 1993: 93 94, n. ${ }^{\circ} 93$.

Fragmento del extremo exterior de un clípeo. Se conserva la parte más externa de la corona de lengüetas rectilíneas, separadas por lanzas, la orla exterior (altura: $5.5 \mathrm{~cm}$ ) y una parte de la superficie externa de la lastra en la que se enmarcaba el tondo. La superficie de esta última se halla alisada en sus caras lateral y anterior, que en la parte central tiene una franja de la superficie trabajada con gradina. Este tratamiento lo diferencia de otros fragmentos que conservan asimismo la superficie exterior de la lastra (véase aquí cat. n. ${ }^{\circ} 7$ ) si bien pensamos que no fue realizado en un segundo momento, sino que pertenece al periodo de creación de la pieza. En el dorso conserva la superficie aplanada y alisada habitual, que en este caso no se ve interrumpida.

La característica más llamativa es la circunstancia de que la orla exterior, correspondiente en la mayoría de los fragmentos de clípeos a la greca entrecruzada con perlas, consiste aquí únicamente en una superficie rugosa irregular. No parece que la trenza haya sido repicada con posterioridad, sino que no llegó a ser finalizada, ya que la superficie del mármol no está rehundida y no se aprecian las huellas que habría dejado el trépano. El motivo debió ser esbozado, dado que, por encima de la lengüeta izquierda, pero sobre todo bajo el listel se aprecian varias líneas convexas yuxtapuestas, que coinciden aproximadamente con las que corresponderían a la delimitación del contorno sinuoso de la trenza. Esta circunstancia abre la posibilidad de que se trate de una pieza inacabada, quizá un desecho de talla.

\section{Fragmento de la corona de un clípeo con lengüeta rectilínea (fig. 7)}

N. ${ }^{\circ}$ inv. 573-3. Mármol lunense. Longitud conservada: $16.5 \mathrm{~cm}$; anchura: $8.5 \mathrm{~cm}$; profundidad: $11.5 \mathrm{~cm}$.

El fragmento presenta una superficie relativamente plana pero irregular alrededor del contorno de la lengüeta, en tanto que en los extremos superior e inferior de esta última tiene una superficie plana, similar a la que muestra el dorso, que además ha sido trabajado para obtener una superficie rugosa.

Gimeno 1990: 1285, n. ${ }^{\circ} 1695$ (?), Koppel 1990: 335, nota 42, Pensabene 1993: 93-94, n. ${ }^{\circ} 93$.

Fragmento de la mitad superior de la lengüeta de un clípeo, perteneciente a la corona. J. Gimeno lo considera como perteneciente a los clípeos con lengüetas curvilíneas y lo atribuye a su "variante C2" (Gimeno 1990: 1274), 

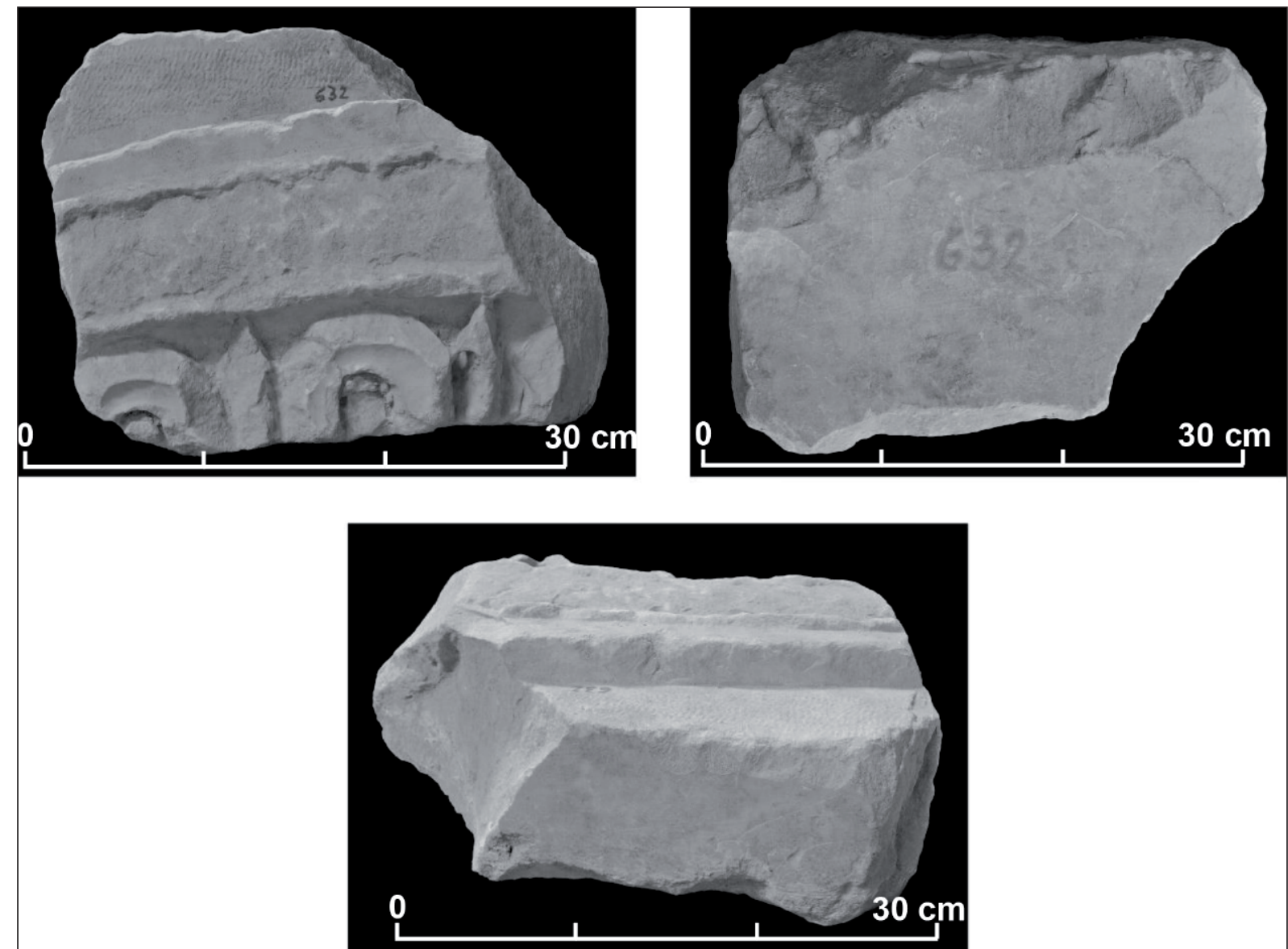

Figura 6. MDT, n. ${ }^{\circ}$ inv. 632. Fragmento de la corona de un clípeo con lengüetas rectilíneas.

Figura 7. MDT, n. ${ }^{\circ}$ inv. 573-3. Fragmento de la corona de un clípeo con lengüeta rectilínea.
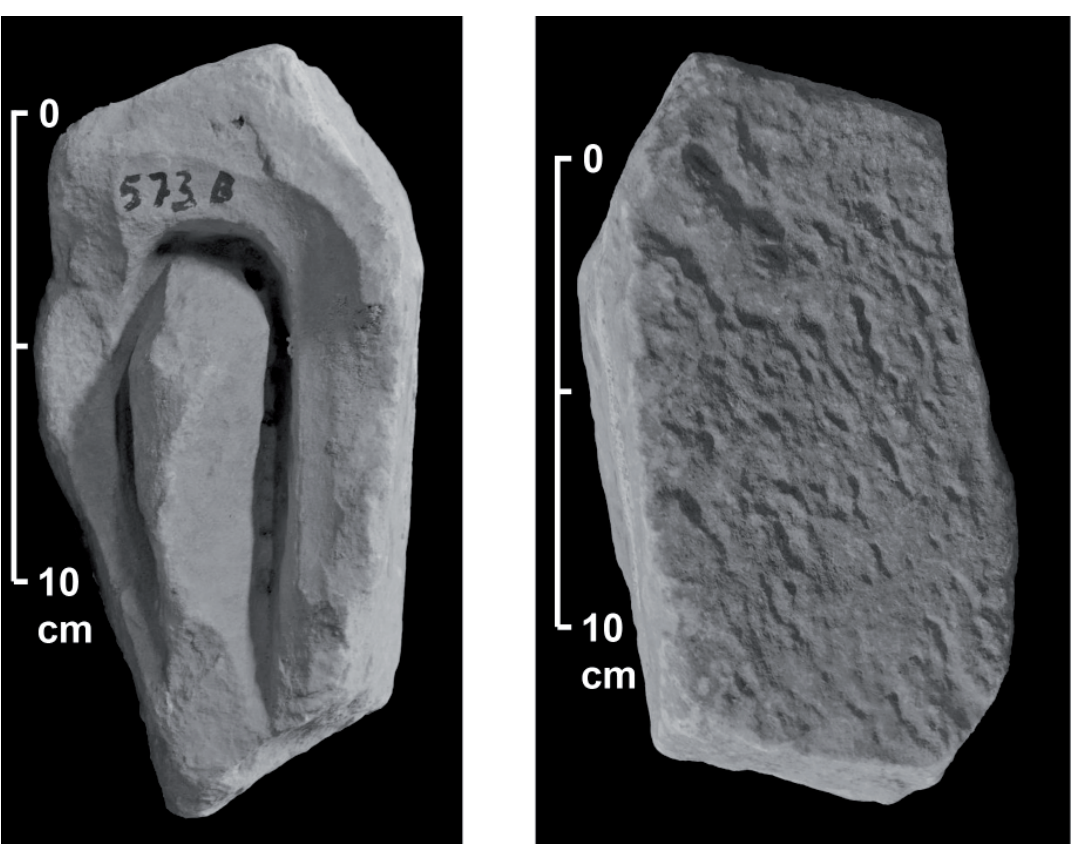

SPAL 29.2 (2020): 147-177 


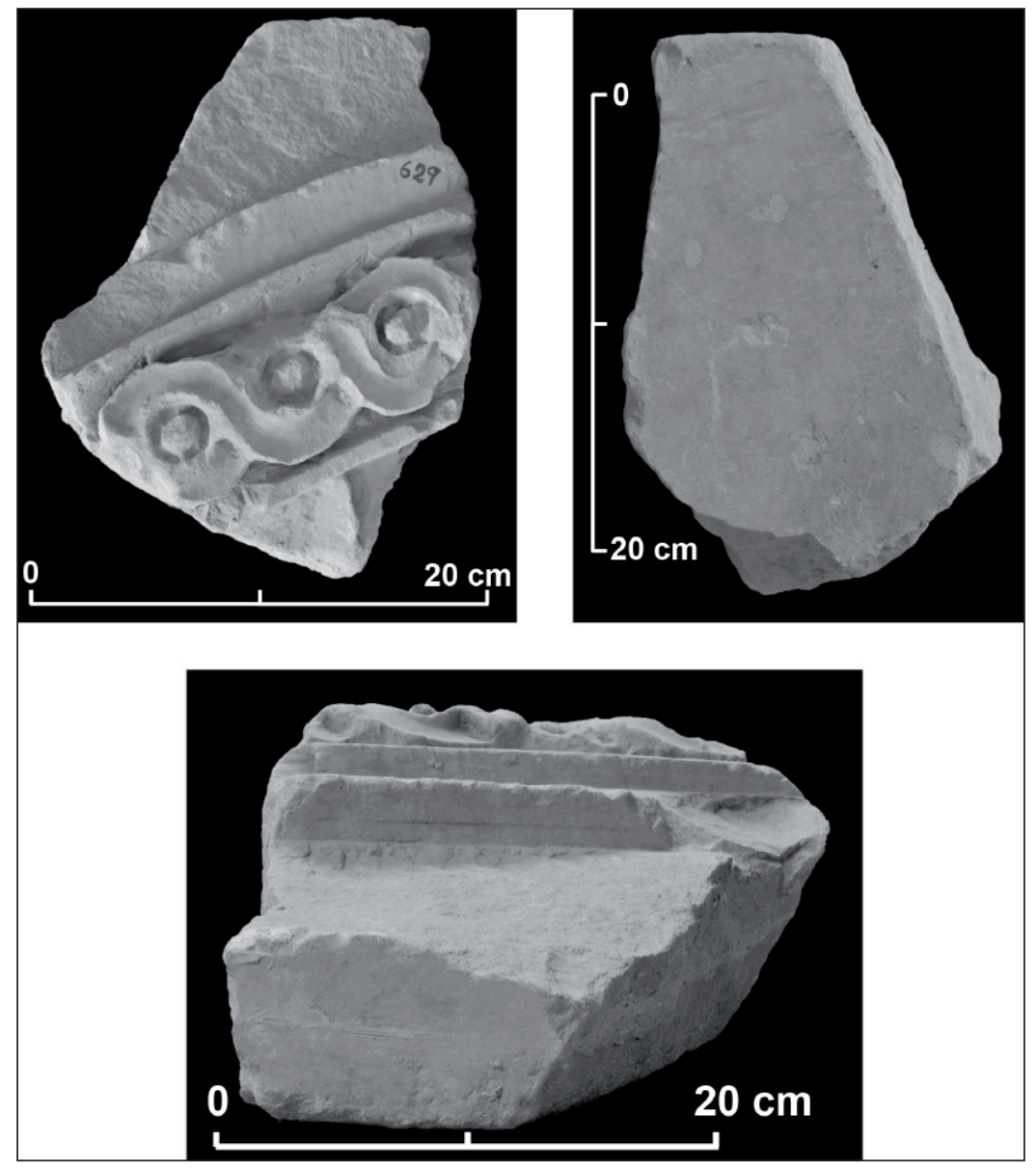

Figura 8. MDT, n. ${ }^{\circ}$ inv. 629.

Fragmento de la corona de un clípeo con lengüetas curvilíneas. caracterizada por mostrar puntas de flecha como elemento de separación. El aspecto original de este ejemplar puede ser reconstruido de manera bastante aproximada por medio de la comparación con el más similar completo que conocemos, que se encuentra en el MHT (Gimeno 1990: 1288, n. ${ }^{\circ} 1710$, Fortuny y Ruiz, en prensa), perteneciente a la misma tipología. En ambos es similar también el tratamiento del contorno del bastón, indicado por medio de un surco realizado con el trépano, pero con toques de esta misma herramienta dispuestos de manera irregular en el interior de dicho surco. Asimismo los dos presentan una inclinación de las lengüetas muy poco pronunciada en relación con otros fragmentos de corona de clípeos con lengüetas curvilíneas (cf. aquí cat. n. ${ }^{\circ} 8$ y 9). Por ello, en nuestra opinión se puede considerar que, tanto el ejemplar mencionado del MHT como el que nos ocupa, en realidad pertenecen a la tipología de lengüetas rectilíneas, como demuestra la comparación con la restitución realizada en el MNAT (véase especialmente el fragmento del extremo inferior del clípeo reconstruido: Koppel 1990: lám. 32e).
Esta impresión se ve confirmada por la mayor anchura del extremo de la lengüeta en relación con las lengüetas de contorno curvilíneo.

Por otra parte, las particularidades que presentan diversos puntos de la superficie del mármol evidencian que este ejemplar es el resultado del recorte de un clípeo, con posterioridad a su amortización, para obtener un elemento de menores dimensiones con una forma aproximadamente rectangular.

\section{Fragmento de la corona de un clípeo con lengüetas curvas (fig. 8)}

N. ${ }^{\circ}$ inv. 629. Mármol lunense. Altura: $24 \mathrm{~cm}$; anchura: $25 \mathrm{~cm}$; profundidad: $11 \mathrm{~cm}$.

La lastra está rota por todos sus lados salvo uno, donde conserva el canto original que está alisado. Las caras anterior y posterior muestran diversos deterioros y desperfectos. 

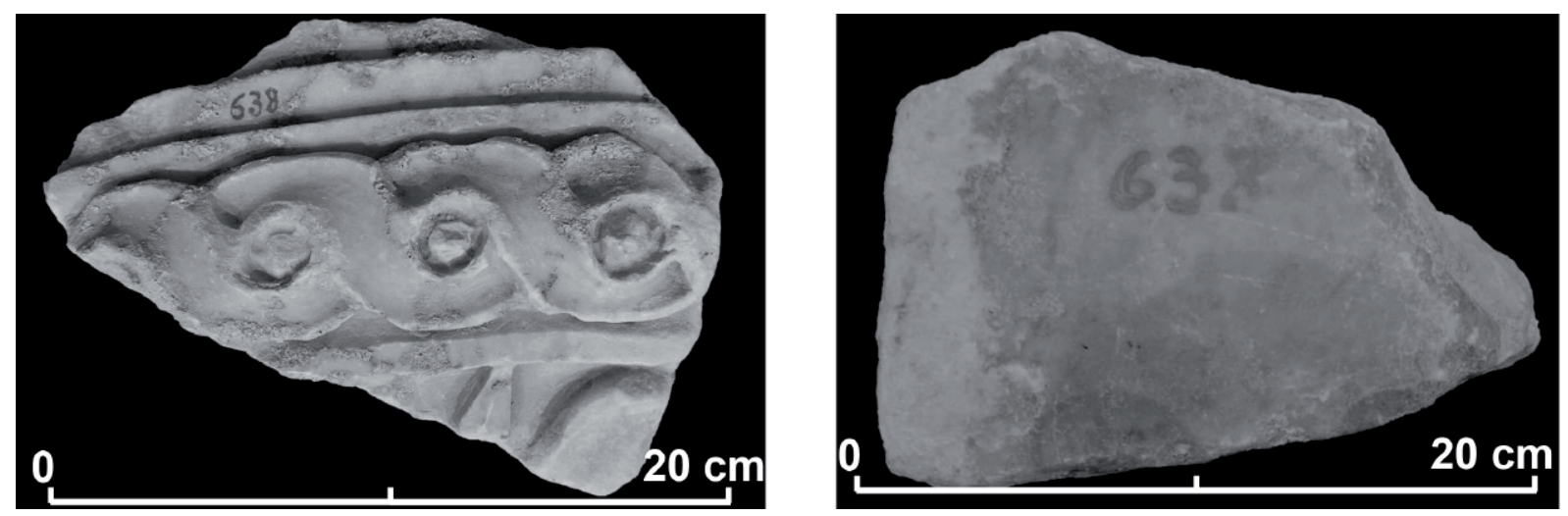

Figura 9. MDT, n. ${ }^{\circ}$ inv. 638. Fragmento de la corona de un clípeo con lengüetas curvilíneas.

Gimeno 1990: 1283, n. ${ }^{\circ}$ 1689, Koppel 1990: 335, nota 42, Pensabene 1993: 93-94, n. ${ }^{\circ} 93$.

Fragmento de la corona de un clípeo. Se conserva un segmento de la zona exterior, correspondiente a la cinta entrelazada ornamentada a su vez con perlas (altura: $6 \mathrm{~cm}$ ) que bordea el clípeo, así como de la corona, decorada con el motivo de lengüetas de las que solo queda el arranque del contorno, separadas aparentemente por lanzas. J. Gimeno lo incluye entre los ejemplares de lengüetas rectilíneas que él denomina como "tipo B" (Gimeno 1990: 1274, 1283-1284, n. ${ }^{\circ} 1689$ 1694), pero se observa con claridad la curvatura que describen, por lo que se puede adscribir a su "tipo C" (Gimeno 1990: 1274, 1285-1290, n. ${ }^{\circ}$ 1695-1716) (esta afirmación es válida asimismo para cat. . $^{\circ} 8$ ). Hay un uso profuso del trépano en el contorno de las perlas y en el espacio exterior de las grecas. Se conserva la superficie alisada del dorso.

Nos ha llegado una parte considerable de la superficie exterior de la placa, fuera del clípeo propiamente dicho. Esta particularidad corrobora la suposición, expresada previamente por otros investigadores, de que los clípeos en realidad estaban inscritos dentro de una lastra cuadrangular. La superficie está repicada con bastante seguridad como fruto de su reutilización, puesto que se conservan vestigios de la superficie alisada original en el extremo junto al borde con la cinta entrelazada, habiéndose rebajado el mármol (cf. cat. n. ${ }^{\circ}$ 5). El canto lateral de la placa conserva la superficie plana original.

\section{Fragmento de la corona de un clípeo con lengüetas curvilíneas (fig. 9)}

N. ${ }^{\circ}$ inv. 638. Mármol lunense. Altura conservada: 15 $\mathrm{cm}$; anchura conservada: $20 \mathrm{~cm}$; profundidad: $10 \mathrm{~cm}$.
La pieza está rota por todos sus lados y muestra diversos desperfectos en ambas caras.

Gimeno 1990: 1283-1284, n. 1690 (con foto), Koppel 1990: 335, nota 42, Pensabene 1993: 93-94, n. ${ }^{\circ} 93$.

Fragmento de la corona de un clípeo, de la que se conserva un segmento de la zona exterior, correspondiente a la cinta entrelazada, ornamentada a su vez con perlas que bordeaba el tondo. El contorno de las perlas está trabajado mediante el trépano. También nos ha llegado una exigua parte del reborde liso exterior. Se conserva asimismo una mínima zona del extremo exterior de la corona, decorada con lengüetas separadas entre sí por flechas. J. Gimeno lo incluye entre los ejemplares de lengüetas rectilíneas ("tipo B"), pero se observa con claridad la curvatura que describen, por lo que se trata de un fragmento que se puede atribuir a su "tipo C" (véase lo expresado en cat. n. ${ }^{\circ} 7$ ). En el dorso conserva la superficie alisada propia de estos ejemplares.

\section{Fragmento de la corona y el reborde exterior de un clípeo (fig. 10)}

N. ${ }^{\circ}$ inv. 633. Mármol lunense. Altura: $20 \mathrm{~cm}$; anchura: $23.5 \mathrm{~cm}$; profundidad: $11.5 \mathrm{~cm}$.

El fragmento está roto por todos sus lados, aunque las superficies de rotura tienen aspectos diferentes. De las lengüetas del clípeo tan solo nos ha llegado el extremo superior de dos de ellas y la punta de la lanza que las separaba.

Gimeno 1990: 1289, n. ${ }^{\circ} 1712$ (?), Koppel 1990: 335, nota 42, Pensabene 1993: 93-94, n. ${ }^{\circ} 93$.

Fragmento de la corona de un clípeo con estrígilos curvilíneos, aparentemente con punta de lanza ("tipo C1" de Gimeno 1990: 1274) que conserva también la orla exterior (altura: $6.5 \mathrm{~cm}$ ) y una porción, aunque 

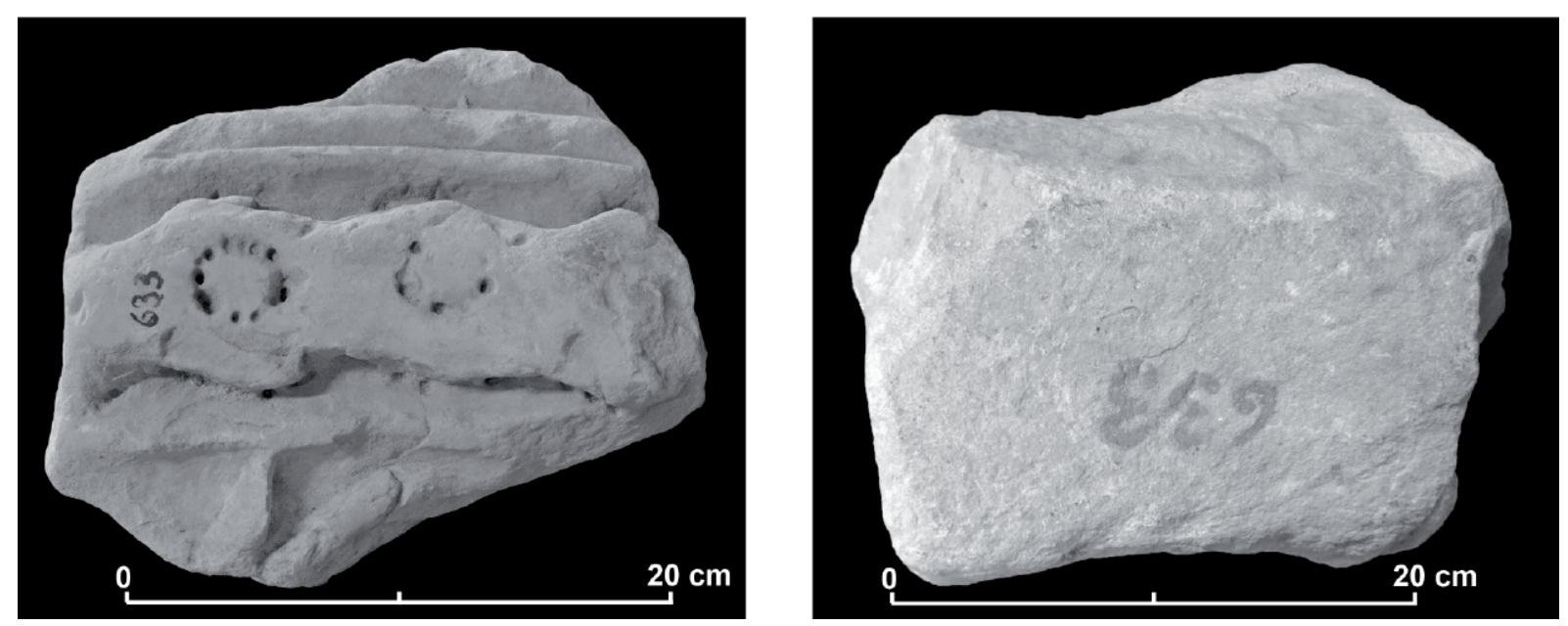

Figura 10. MDT, n. ${ }^{\circ}$ inv. 633. Fragmento de la corona y el reborde de un clípeo.

muy escasa, de la superficie de la placa rectangular exterior en la que se hallaba enmarcado el clípeo.

Este fragmento es uno de los más interesantes para el estudio de las diversas fases de trabajo de los clípeos del foro provincial. Algunos detalles nos permiten pensar que se trata de un ejemplar inacabado, lo que se ve apoyado por medio de la comparación con piezas que comprenden aproximadamente la misma zona del clípeo, como p.ej. cat. n. ${ }^{\circ}$ 8. No está claro, debido a su estado de conservación, si esta afirmación es válida para la zona de las lengüetas, pero la hipótesis se ve avalada por sus particularidades en la zona de la greca entrecruzada. Esta ha sido únicamente esbozada, al igual que el contorno de las perlas cuya delimitación únicamente se ha proyectado, además de manera desigual, mediante toques de trépano, dando como resultado la apariencia de un trabajo burdo y esquemático. Otro detalle que llama la atención es la altura de esta orla, que es de $10 \mathrm{~cm}$, algo mayor al de los fragmentos análogos cat. n. ${ }^{\circ} 5$ y 7 ( 7.5 y $8 \mathrm{~cm}$ de altura respectivamente contando el marco). Debido a esta circunstancia, es posible que la pieza fuese desechada antes de haber sido terminada debido a un error de cálculo en su trazado. En cuanto al dorso, su superficie es plana pero no alisada como sería lo habitual, sin que ello se deba a una reelaboración posterior dado que conserva la profundidad que le corresponde a los clípeos en el reborde exterior. Pese a todo lo indicado, diversos indicios permiten suponer que este ejemplar fue reutilizado en un momento posterior. Por ello la pieza, cuyas circunstancias exactas de hallazgo ignoramos, debió ser hallada en un contexto secundario.
10. Fragmento de una lastra decorada con un candelabro (fig. 11)

N. ${ }^{\circ}$ inv. 599. Mármol lunense. Altura conservada: 12 cm; anchura: $27 \mathrm{~cm}$; profundidad: $14 / 18.5 \mathrm{~cm}$.

La pieza está extremadamente fragmentada. Tan solo conserva una pequeña parte de la cara anterior y del dorso, así como un exiguo vestigio de la superficie original en el lateral izquierdo.

Inédito

Fragmento de una lastra con el exiguo resto de un motivo en relieve, esculpido sobre un fondo liso y enmarcado por un kyma lésbico. A pesar del deterioro, sus dimensiones y la comparación con otros ejemplares similares procedentes de Tarraco permiten reconocerlo como un fragmento más de una serie bien conocida de relieves arquitectónicos decorados con candelabros vegetales (Gimeno 1990: 1224-1234, n. ${ }^{\circ} 1621-1637$, Pensabene 1993: 98-100, n. ${ }^{\circ}$ 96-100, Macias et al. 2007: 780, fig. 9,1). El ejemplar conserva, en lo referente a la superficie esculpida, únicamente un extremo del recipiente marmóreo sobre el que, en otras piezas, está esculpido el fuego (el más comparable es Gimeno 1990: 1229-1230, n. ${ }^{\circ} 1627$, Pensabene 1993: 98, n. $^{\circ}$ 96, Pensabene y Domingo 2019: 81, fig. 31, arriba). Según sabemos por comparación con los fragmentos de Tarragona, con bastante probabilidad el candelabro se apoyaba sobre una base con tres patas felinas.

La ubicación del conjunto de candelabros vegetales en la terraza superior de la acrópolis de Tarraco ha suscitado diversas controversias. Según la opinión más 

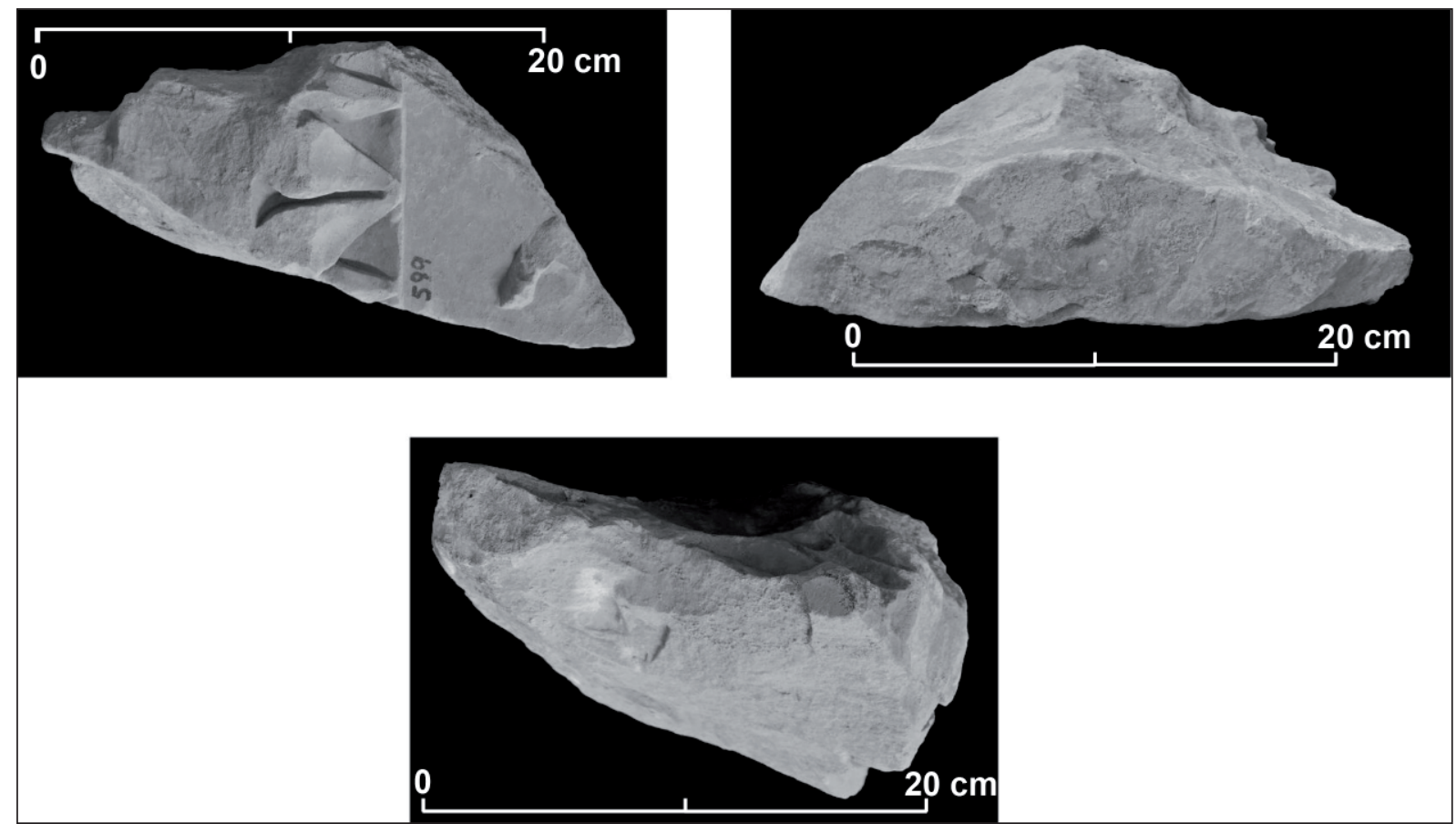

Figura 11. MDT, n. ${ }^{\circ}$ inv. 599. Fragmento de una lastra decorada con un candelabro.

extendida debían situarse en el ático de los pórticos, como motivo de separación entre los clípeos de Júpiter Amón y Medusa, sustituyendo por lo tanto a las cariátides, que actúan con la misma función en Roma y otras ciudades (véanse últimamente: Peña 2018, Pensabene y Domingo 2019: 77-83, figs. 28.30 con mención de las diversas teorías y la bibliografía anterior). Recientemente se ha propuesto excluir esta posibilidad en beneficio de la existencia efectiva de dichas figuras femeninas (Pensabene y Domingo 2019: 81-83, fig. 33), si bien los argumentos expresados para sostener esta hipótesis no resultan convincentes (Peña, en prensa), por lo que continúa siendo más probable la teoría de A. Peña, que sostiene que los relieves con candelabros debieron servir como elemento de separación entre los clípeos (Peña 2018, 176-182, Peña, en prensa).

\subsection{Jardín de Santa Tecla la Vella (octubre de 1933) (fig. 1c)}

11. Fragmento de un relieve con cabeza de un león (fig. 12)

N. ${ }^{\circ}$ inv. 5080. Mármol lunense. Altura: $14.5 \mathrm{~cm}$; anchura: $13.5 \mathrm{~cm}$; profundidad: $14.8 \mathrm{~cm}$.
Se conserva la mitad superior de la cabeza del animal. La lastra está rota por todos lados salvo el izquierdo.

\section{Inédito}

Fragmento de una cabeza de león en relieve, perteneciente a la parte superior de un elemento de forma triangular, cuyo contorno está delimitado por una ancha franja rectilínea de superficie plana y alisada. Debido a su deterioro no podemos reconocer el elemento al que perteneció, aunque es seguro que no constaba únicamente de este motivo ya que, junto al lado derecho desde el punto de vista del espectador, se ve el arranque de otro elemento irreconocible. En la parte superior del lado izquierdo se conserva la superficie original, que es plana pero está trabajada con el puntero para que sea rugosa, y que debió extenderse al lateral contrario si bien debido a su rotura se ha perdido.

El estado de conservación de este ejemplar dificulta establecer una datación precisa, siendo sus características más significativas el labrado de los motivos de la testa por medio de estrías no muy profundas y el hecho de que los ojos tienen indicadas las pupilas por medio de orificios circulares, con un empleo del trépano prácticamente inexistente. Asimismo, su fragmentación 


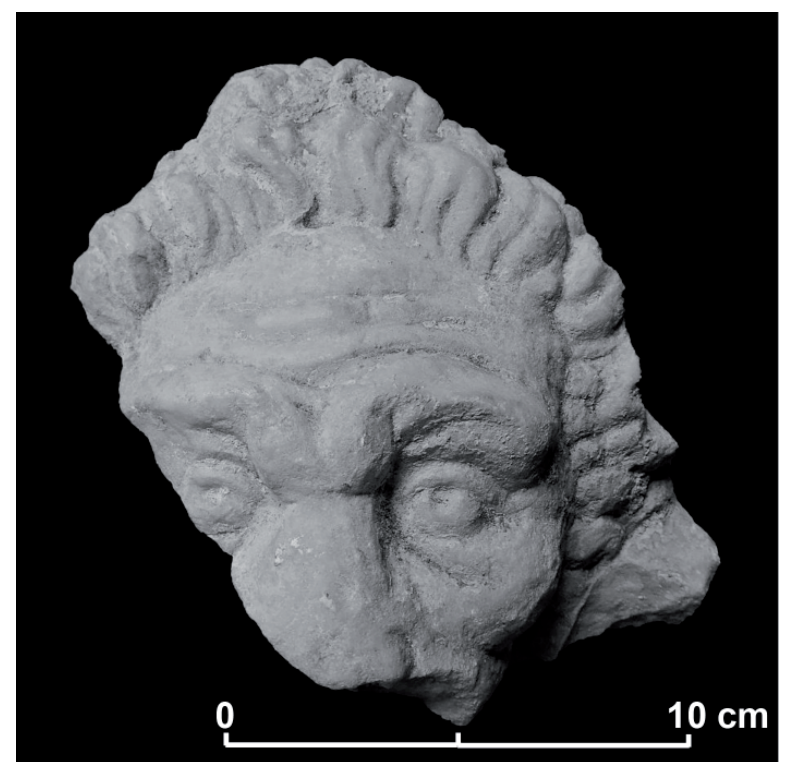

Figura 12. MDT, n. ${ }^{\circ}$ inv. 5080. Fragmento de un relieve con cabeza de león.

impide identificar con seguridad su función concreta, aunque el tratamiento de la superficie del mármol en las zonas superior y posterior permite suponer que fue concebido para ser encastado en un soporte o monumento, probablemente asociado a un contexto arquitectónico. Por diversos motivos puede ser relacionado con otras piezas recuperadas en excavaciones desarrolladas en diversos puntos de la catedral. La primera, hallada en 2000 en un nivel de desmonte de época tardoantigua, es una lastra decorada con una cabeza de león que, al igual que la que nos ocupa, está demasiado fragmentada como para poder determinar su función precisa (Macias et al. 2007: 782, fig. 11,2, Macias et al. 2011: 196-197, fig. 4,4, Macias et al. 2012: 33, n. ${ }^{\circ}$ 1.2.17). No obstante, la coincidencia en cuanto al motivo representado es la única característica común a ambas, puesto que la pieza que estudiamos es de dimensiones algo menores y de diversa forma, mostrando asimismo particularidades en su labra totalmente diferentes. El ejemplar hallado en el año 2000 se ha propuesto relacionarlo con el coronamiento de un porticado, actuando posiblemente como gárgola para la evacuación de agua, posibilidad que podríamos hacer extensiva al ejemplar del MDT. De ser así y en el caso de que hubieran pertenecido a un mismo edificio, ambas estarían situadas en lugares distintos de su alzado, siendo probable que decorasen construcciones diversas. No obstante, el estado en que han llegado a nuestros días ambos ejemplares impide corroborar esta hipótesis, ya que la falta de la parte inferior impide comprobar si existía un orificio, en la parte correspondiente a la boca, para la salida de agua. En cambio, esta particularidad puede reconocerse en el fragmento de una cabeza, hallada en 1989 durante las excavaciones del Instituto Arqueológico Alemán (Hauschild 1992: 116, fig. 14), asimismo excesivamente fragmentada por lo que ni siquiera es posible reconocer si representaba también a un león. Pese a la existencia del orificio, en este caso de forma cuadrangular, no es segura su atribución a la cubierta de un edificio, puesto que no puede descartarse que hubiera funcionado como surtidor de una fuente.

Debido a sus características, nos resulta muy sugerente la comparación de esta pieza del MDT con un ejemplar procedente del Traianeum de Italica (Vargas 2018: 220-221, fig. 14), que muestra en su parte posterior una forma triangular muy similar y que conserva el orificio en la zona de la boca. Este ha sido interpretado como el remate decorado de un imbrex, actuando como evacuador de agua, asociado a la techumbre marmórea de este templo de la que se conservan diversos elementos (Vargas 2018). Por lo que respecta al ejemplar que nos ocupa, de poder confirmarse una misma función, podríamos abrir la posibilidad de que el templo al $d i$ vus Augustus o su pórtico dispusieran de una cubierta en mármol, de manera similar al caso italicense. Sin embargo, no se conocen otros elementos de construcción -como p.ej. imbrices - realizados en mármol que se puedan atribuir a la techumbre este edificio.

12. Fragmento de la corona de un clípeo decorada con meandros (fig. 13)

N. ${ }^{\circ}$ inv. 3843. Mármol lunense. Altura: $14.5 \mathrm{~cm}$; anchura: $24 \mathrm{~cm}$; profundidad: $8.5 / 12 \mathrm{~cm}$.

La pieza, rota por todos sus lados, se halla muy fragmentada y muestra múltiples deterioros en la cara anterior. El dorso tiene numerosos arañazos y desperfectos.

Inédito.

Fragmento de un clípeo correspondiente a una máscara de Júpiter Amón, del que nos ha llegado únicamente un exiguo resto de la parte central de la corona, que comprende restos de dos meandros. Es de forma cóncava, por lo que debe pertenecer a la zona más cercana a la parte exterior de la decoración perimetral. El contorno de los elementos parece únicamente esbozado y los motivos del relieve que se conservan muestran un menor realce en comparación con los fragmentos de clípeos 
que nos han llegado en mejor estado. No creemos posible que se deba a su reutilización, sino que más bien parece que se trata de una pieza sin terminar de elaborar, correspondiente a un desecho de talla. Sin embargo, la valoración de esta particularidad se ve limitada debido a su mal estado de conservación. El dorso muestra la superficie plana y alisada habitual.

Al igual que otras numerosas piezas análogas, está reelaborado con posterioridad a su amortización. En este caso se ha recortado para obtener una forma semicircular, de manera similar a cat. n. ${ }^{0} 7$, como se reconoce especialmente en el dorso. Este último debió ser la cara visible en su segundo uso. En uno de sus laterales la superficie es plana y rectilínea, aunque irregular, lo que evidencia la reutilización.

\section{Fragmento de un clípeo con} prótomo de Medusa (fig. 14)

N. ${ }^{\circ}$ inv. 3844. Mármol lunense. Altura: $35 \mathrm{~cm}$; anchura: $19 \mathrm{~cm}$; profundidad: $10 / 13.5 \mathrm{~cm}$.

La pieza está rota por todos sus lados. De la cara no se conserva nada ya que muestra una superficie de rotura.

Koppel 1990: 335, nota 42, Pensabene 1993: $93-$ 94, n. ${ }^{\circ} 93$.

Fragmento de un clípeo, del que se conserva una parte de la máscara central y de un sector de la parte interior de la corona de lengüetas rectilíneas, con motivos semicirculares de superficie plana en su arranque inferior. La zona correspondiente al prótomo se halla ocupada por una serie de cabellos dispuestos de manera alborotada que enmarcaban la cara que, aunque no se conserva, puede ser identificada como una Gorgona (Krauskopf 1988, Paoletti 1988), con ejemplares semejantes en cuanto a la disposición de los cabellos en Mérida (ejemplar completo: De la Barrera 2000: 80, n. ${ }^{\circ} 247$, lám. 97, Goldbeck 2015: 74, fig. 94; pieza fragmentada: De la Barrera 2000: 80, n. ${ }^{\circ}$ 248, lám. 98), pudiendo también ser comparado con prótomos procedentes de Aquileia (Goldbeck 2015: 118-119.121, figs. 178.191).

Esta pieza es muy diferente, desde los puntos de vista formal y estilístico, a la única máscara que conserva una representación atribuida a Medusa de un clípeo de Tarragona (Koppel 1990: 334-335.337, lám. 32c, Pensabene 1993: 91-92, n. ${ }^{\circ} 82$ ). Por el contrario, algunas particularidades lo hacen comparable a un fragmento recuperado hace algunos años, en el que también se ha reconocido la imagen de la misma figura mitológica (Macias et al. 2007: 779, fig. 6,3, Macias et al. 2011: 192, fig. 3,5, Macias et al. 2012: 32, n. ${ }^{\circ}$ 1.2.14,

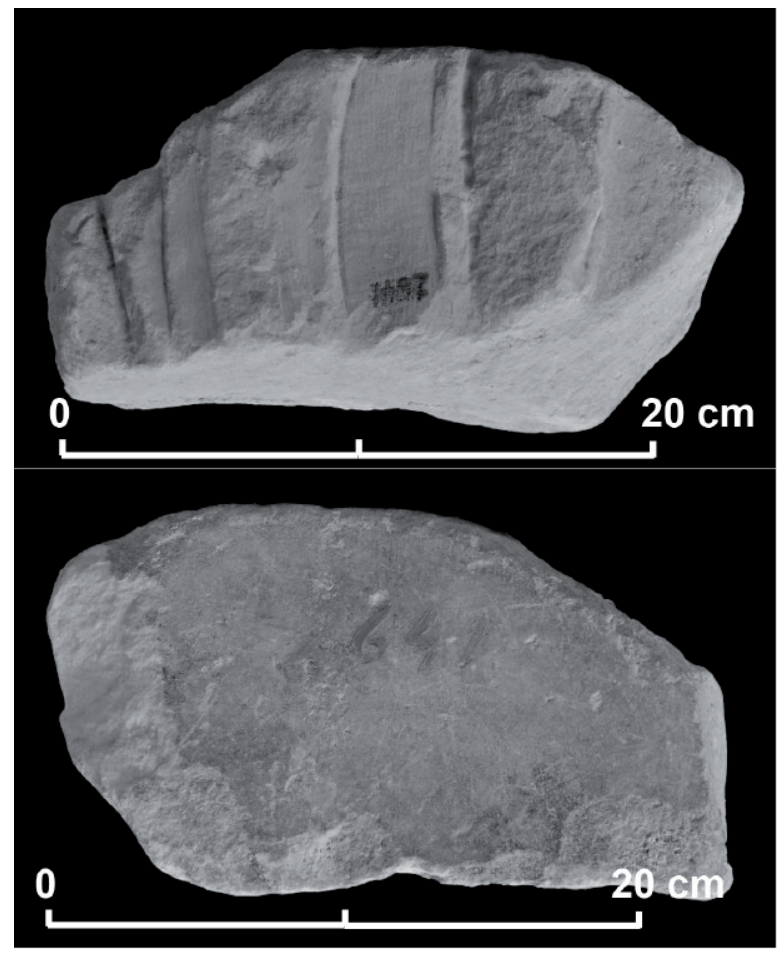

Figura 13. MDT, n. ${ }^{\circ}$ inv. 3843. Fragmento de la corona de un clípeo decorada con meandros.

Peña 2018: 173, fig. 4b). Este último está inacabado, ya que conserva la superficie del mármol sin desbastar en su totalidad y tan sólo se han delimitado y esbozado dos gruesos mechones. Tiene en común con el ejemplar que nos ocupa la característica de que ninguno de los dos presenta espacio para la hilera de perlas. Además, en la pieza del MDT el prótomo ocupa todo el espacio disponible del emblema central, invadiendo no solo el margen que lo separa de la corona sino incluso el lugar que, en los clípeos con máscaras de Júpiter Amón, está reservado a la hilera de perlas que las delimita. La ausencia de perlas, unida a las reducidas dimensiones de la cabeza y al hecho de que esta no presenta una forma totalmente circular, nos permiten suponer que este fragmento también corresponde a una pieza que no fue terminada, siendo posible que se trate de un desecho de talla. Esta impresión parece verse corroborada mediante la comparación con otro fragmento de la misma tipología de lengüetas (cat. n. ${ }^{\circ}$ 14) que, al contrario de la que aquí estudiamos, presenta la hilera de perlas y muestra una labra más esmerada de los mechones. En el ejemplar que nos ocupa, las guedejas están trabajadas a base de profundos y anchos surcos realizados con el trépano, empleado asimismo para realizar el surco 

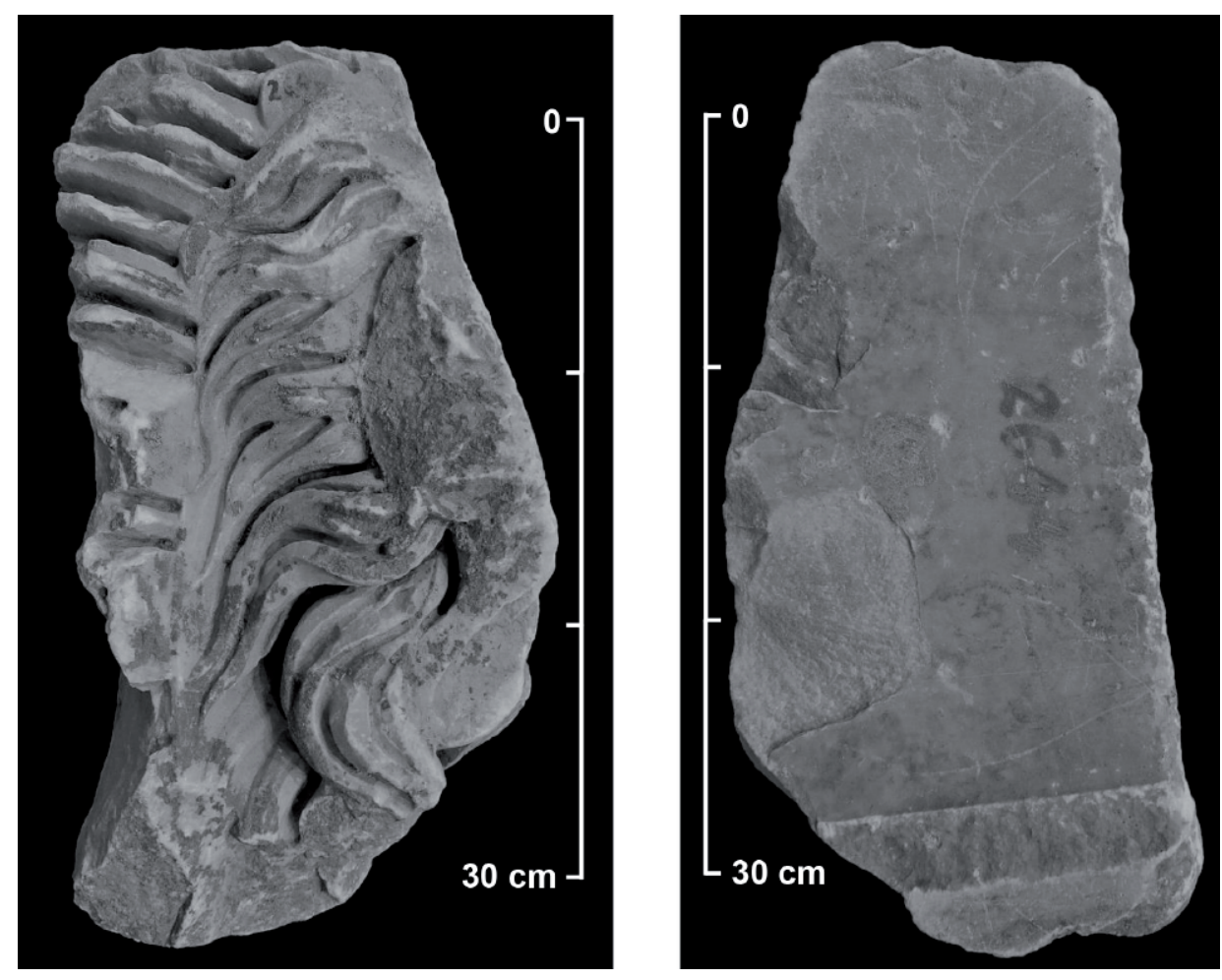

Figura 14.

MDT, n. ${ }^{\circ}$ inv. 3844

Fragmento de un

clípeo con prótomo de Medusa.

de contorno que delimita el rostro, herramienta que ha sido utilizada, aunque con mayor habilidad en una de las máscaras de Júpiter Amón que se conserva en mayor medida (Koppel 1990: 332-335.338, lám. 32b, Pensabene 1993: 91, n. ${ }^{\circ} 86$ ). Sus particularidades desde el punto de vista técnico no deben ser interpretadas como indicio de una datación más tardía, sino que, junto a otras características, ponen de manifiesto la actuación de talleres o artesanos distintos. Por ello, ante otras hipótesis como una posible reparación posterior, nos parece más probable una datación flavia. La apariencia burda del trabajo de los mechones podría atribuirse, al igual que las particularidades ya mencionadas, a que la pieza se quedó en un estadio de semielaboración.

La superficie del dorso está alisada como es habitual, pero queda interrumpida por una franja rectilínea que marca dos niveles escalonados y que posiblemente se debe a los restos del sistema de anclaje. La superficie del mármol en esta franja presenta huellas de sierra como producto de su recorte. Estas mismas particularidades han sido detectadas en otro fragmento del MDT (cat. n. ${ }^{\circ}$ ) y ya eran conocidas por medio de dos ejemplares recuperados hace algunos años, de los que tenemos fotografía del dorso: el fragmento de clípeo de Medusa inacabado, que hemos mencionado anteriormente, y una segunda pieza que muestra parte del rostro de Júpiter Amón (Macias et al. 2007: 778, fig. 7, Macias et al. 2011: 192, fig. 3,1, Macias et al. 2012: 32, n. $\left.{ }^{\circ} 1.2 .15\right)$.

\section{Fragmento de un clípeo con prótomo de} Medusa (?) y lengüetas rectilíneas (fig. 15)

N. ${ }^{o}$ inv. 3816. Mármol lunense. Altura conservada: 32 $\mathrm{cm}$; anchura conservada: $50 \mathrm{~cm}$; profundidad: $16 \mathrm{~cm}$.

Está roto por todos sus lados. La superficie muestra numerosos deterioros y desperfectos de diversa índole.

Inédito

Fragmento de un clípeo que contiene un sector de las partes central e interior de la corona, y del que se conserva además la hilera de perlas que enmarca el prótomo central. Las lengüetas son rectilíneas, como en cat. $n .^{\circ} 6$ y 21 . Al igual que en otros fragmentos se constata la destrucción o arranque intencional del prótomo, como demuestra la superficie justo en el plano de rotura junto a la hilera de perlas, lo que ha ocasionado la pérdida de la máscara con representación de divinidad.

La característica más significativa de esta pieza la constituyen los gruesos mechones que quedan 


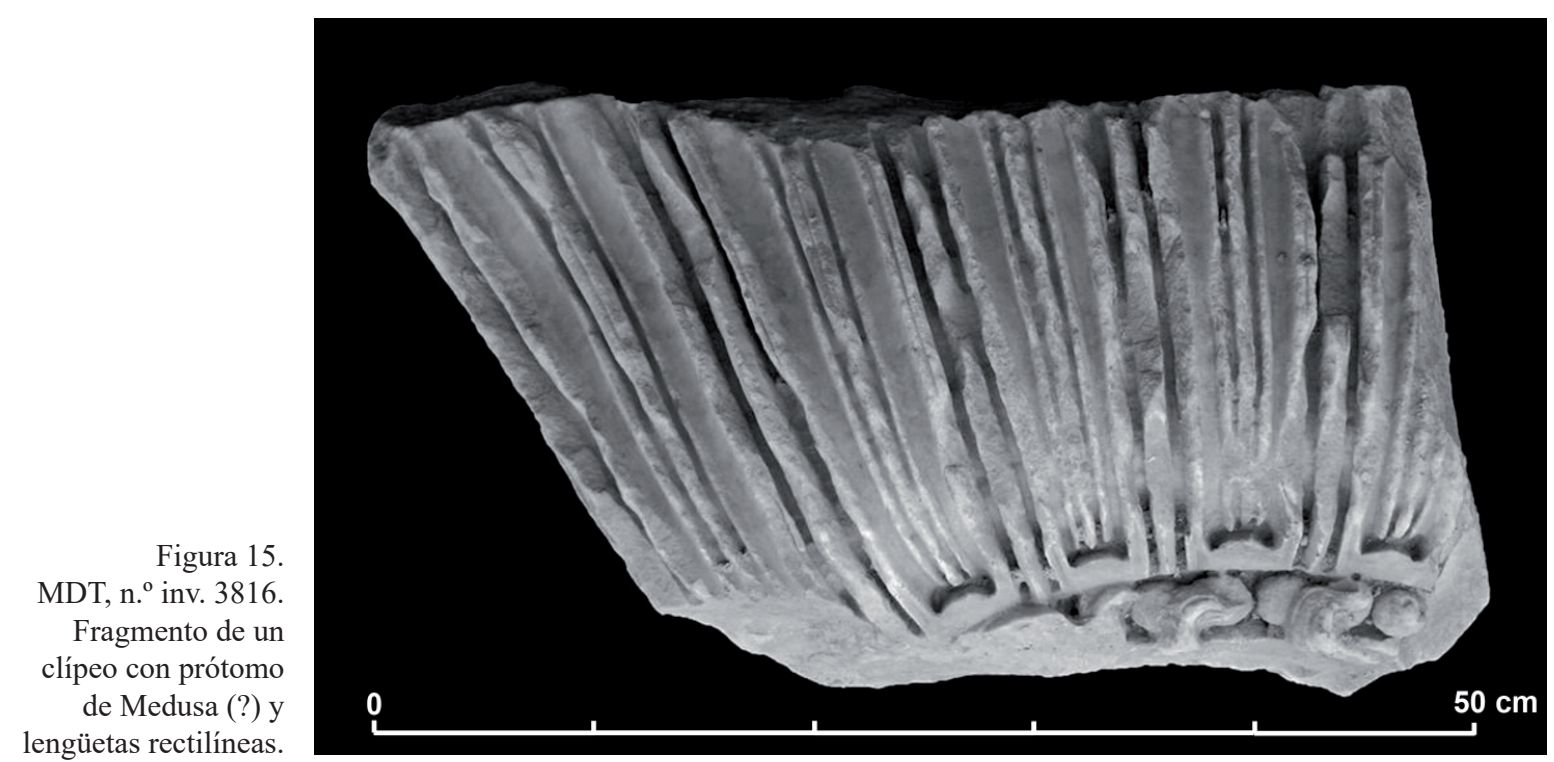

estructurados en su interior por estrías y que terminan en puntas mucho más finas. Estas guedejas se superponen a la hilera de perlas dispuestas de manera aislada entre ellas. El estado fragmentado nos impide determinar con seguridad a quién representaba la máscara del prótomo central de este clípeo, ya que no se conoce ningún ejemplar de características similares. Los restos de los tres pequeños mechones que se conservan se asemejan en cierto modo a los que muestran la barba y el cabello de dos de las máscaras de Júpiter Amón mejor conservadas (una conocida desde hace tiempo: Koppel 1990: 333-334, 337, lám. 32a, Pensabene 1993: 89-90, n. ${ }^{\circ} 85$; la segunda recuperada recientemente: Macias et al. 2007: 778, fig. 7, Macias et al. 2011: 192, fig. 3,1, Macias et al. 2012: 32, n. $\left.^{\circ} 1.2 .15\right)$ y a los de una más fragmentada atribuida a Medusa (Koppel 1990: 334335.337, lám. 32c, Pensabene 1993: 91-92, n. ${ }^{\circ}$ 82). Sin embargo, el parecido con respecto a los clípeos de Júpiter Amón es únicamente estilístico, como evidencia la comparación con los ejemplares más completos (Koppel 1990: 332-339, láms. 32a-b, Pensabene 1993: 89-91, n. $\left.{ }^{\circ} 85-86\right)$. Además de mostrar las máscaras claramente separadas de la hilera de perlas, característica que también se comprueba en los ejemplares más fragmentados (véase aquí cat. n. ${ }^{\circ}$ ), la disposición y la distribución de los mechones es diferente. Por ello, descartamos que represente a esta divinidad masculina, siendo por lo tanto más probable que represente a Medusa, estando en consonancia con la característica disposición alborotada de sus cabellos. Esta suposición puede verse avalada por el hecho de que los otros fragmentos conocidos de los que se supone que representan a Medusa (ejemplar en el MNAT: Macias et al. 2007: 779, fig. 6,3, Macias et al. 2012: 32, n. ${ }^{\circ}$ 1.2.14, Peña 2018: 173, fig. 4b; ejemplar del MDT véase aquí cat. n. $\left.{ }^{\circ} 13\right)$ muestran la corona decorada con la misma tipología de lengüetas. Además, en el cat. n. ${ }^{\circ} 13$ los cabellos invaden directamente la totalidad de la hilera, hasta el punto de que esta no es visible como mínimo en la parte conservada. Aun así, tampoco pueden ponerse en relación directa, debido a las diferencias en el labrado de los cabellos.

\section{Fragmento de un clípeo (desaparecido)}

N. ${ }^{\circ}$ inv. 3822. Presumiblemente mármol de Luni-Carrara. Altura: $15 \mathrm{~cm}$; anchura: $11 \mathrm{~cm}$.

\section{Inédito}

Fragmento de un clípeo de tipología indeterminada. Su existencia está documentada únicamente a través del libro de registro del museo.

16. Fragmento de un bloque con relieve de armas (fig. 16)

N. ${ }^{\circ}$ inv. 3367. Mármol lunense. Altura conservada: $29 \mathrm{~cm}$; anchura conservada: $35 \mathrm{~cm}$; profundidad: $10 / 18.5 \mathrm{~cm}$.

El bloque está roto por todos sus lados. Los motivos decorativos presentan diversos deterioros. 
Inédito

Fragmento de un bloque con decoración en relieve dispuesta en dos niveles. En el nivel superior se ve un escudo de forma romboidal, cuyo interior está decorado con motivos que remiten al armamento de la cultura celta (Rapin 1999, Lejars 2007), al igual que un segundo escudo al que se superpone el primero, sirviéndole de fondo, decorado con motivos similares. La parte posterior del bloque presenta una superficie lisa.

Tanto por el formato como por las dimensiones, este bloque debió pertenecer a un contexto arquitectónico, si bien no tenemos datos suficientes que nos permitan conocer su lugar de exposición exacto, ni podemos saber si estaba asociado a un edificio o a un monumento honorífico exento. Por lo que respecta a la iconografía, esta pieza es un ejemplo más de la difusión de la propaganda imperial, expresada mediante el tema de la acumulación de armas (Polito 1998), una de cuyas mayores expresiones se encuentra en el Foro de Trajano (Ungaro 2017). En Hispania tuvo una difusión significativa, destacando, por lo que respecta a contextos públicos oficiales, los relieves de Mérida, tanto los del sacrarium del teatro (Nogales 2011: 421-422, fig. 3b.d, Nogales 2017: 462, n. ${ }^{\circ}$ 61) como los del templo de Marte (Nogales 2011: 422, fig. 3c, León 2015). El estado de conservación del ejemplar del MDT no solo nos impide conocer su significado concreto sino también precisar su cronología, si bien proponemos una

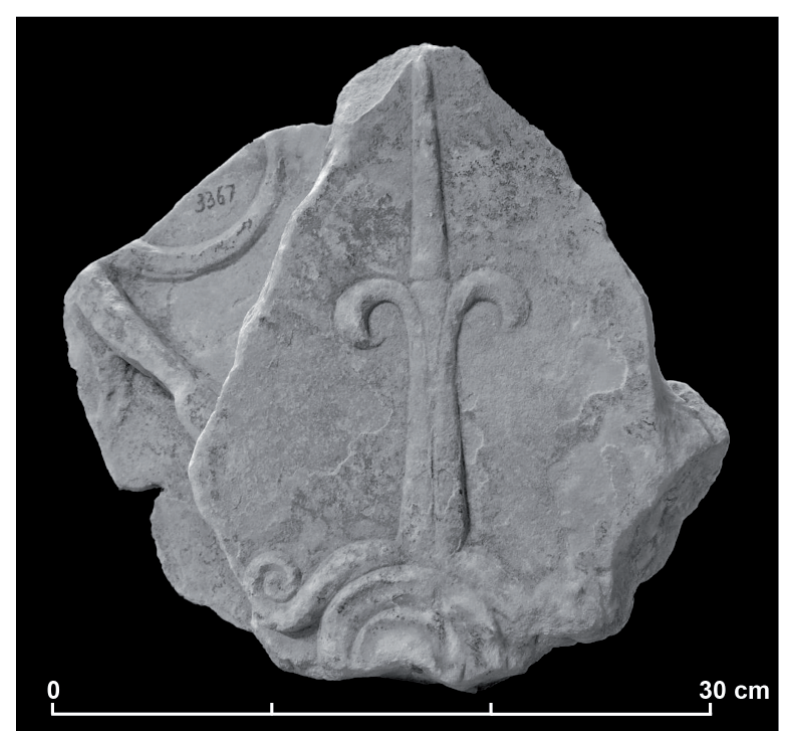

Figura 16. MDT, n. ${ }^{\text {o }}$ inv. 3367. Fragmento de un relieve de armas. datación, por comparación con los ejemplares mencionados, a finales del siglo I o inicios del siglo II d.C.

\subsection{Puntos indeterminados de la catedral y su entorno}

17. Fragmento de ropaje de una estatua (fig. 17)

N. ${ }^{\circ}$ inv. 1629. Mármol blanco de grano medio-fino (¿Paros?). Altura conservada: $11.2 \mathrm{~cm}$; anchura: 12.5 $\mathrm{cm}$; profundidad: $7.5 \mathrm{~cm}$.

Está fracturado por todos sus lados salvo la parte frontal y derecha. Presenta numerosos deterioros y desperfectos de diversa índole.

Inédito

Fragmento de ropaje de una estatua de tamaño natural o mayor. Los pliegues están estructurados mediante elevaciones y depresiones, para lo cual se ha utilizado profusamente el trépano; que a veces son anchos y superficiales y otras son más estrechos y profundizan en mayor medida en el volumen del tejido. En el centro, un pliegue de menores dimensiones y de superficie más plana se halla superpuesto al plegado principal.

Debido a la forma del fragmento conservado, es patente que no corresponde al tejido junto a la anatomía del cuerpo de la imagen, sino que corresponde a la caída de pliegues, quizá de un manto o paludamentum, que pendía de la figura, posiblemente en el lateral izquierdo. Como una de las partes más frágiles de la escultura, debió desprenderse cuando esta se rompió tras su amortización.

\section{Fragmento de ropaje de una estatua (fig. 18)}

N. ${ }^{\circ}$ inv. 6238. Mármol blanco de grano fino, posiblemente de Luni-Carrara. Altura conservada: $8.5 \mathrm{~cm}$; anchura: $11.3 \mathrm{~cm}$; profundidad: $9.3 \mathrm{~cm}$.

El fragmento está roto por sus caras superior e inferior, así como por la parte trasera de los laterales. Tiene deterioros graves en la parte frontal y los laterales.

Inédito

Fragmento de ropaje de una estatua exenta de grandes dimensiones. Los pliegues están estructurados por medio de elevaciones y depresiones, estando separados mediante canales relativamente profundos. En el 

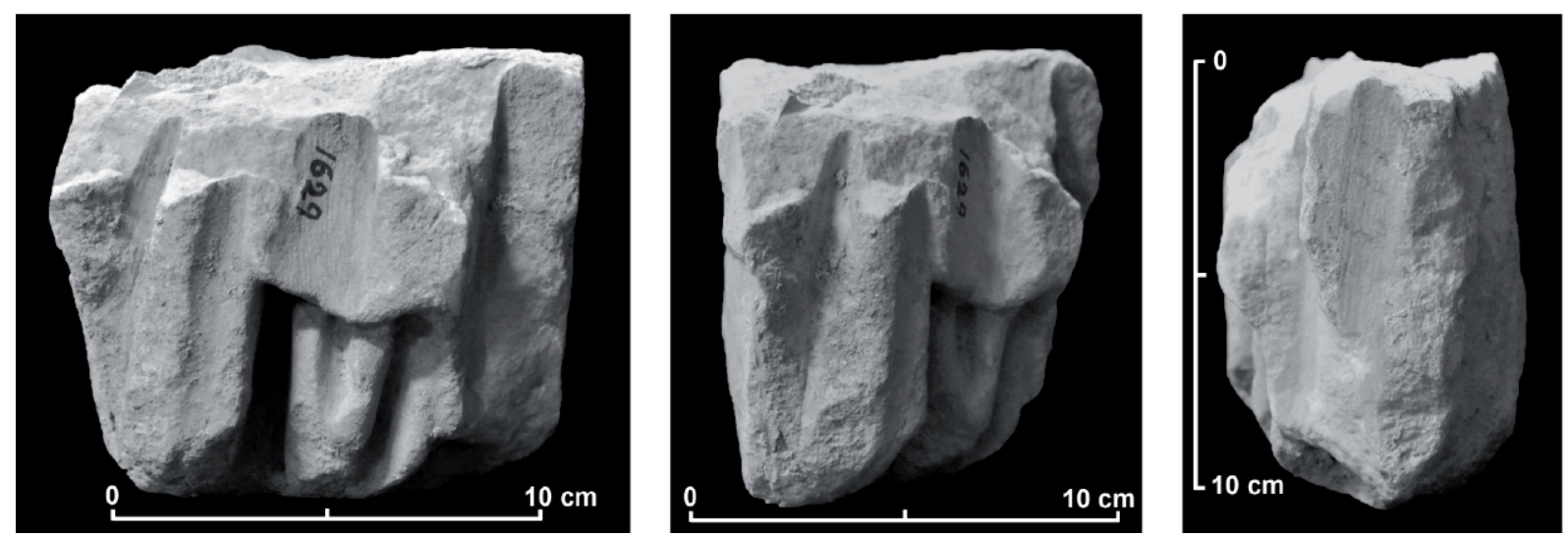

Figura 17. MDT, n. ${ }^{\circ}$ inv. 1629. Fragmento de ropaje.
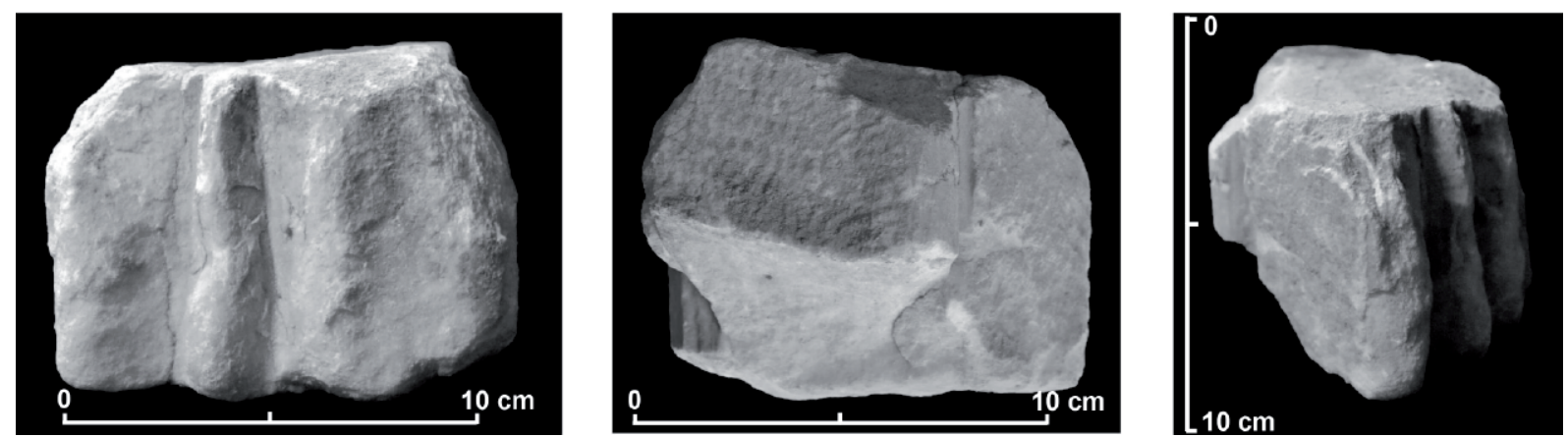

Figura 18. MDT, n. ${ }^{\circ}$ inv. 6238. Fragmento de ropaje.

extremo derecho, desde el punto de vista del que lo mira, la separación se produce de manera más progresiva. Por detrás de los pliegues de los extremos de ambos laterales se ven dos anchos canales realizados con el trépano, que profundiza en la superficie del mármol, especialmente en el lateral derecho. En el dorso se observa una superficie sin trabajo escultórico, sino alisada y tratada con la gradina, lo que evidencia que esta zona no se veía, pero que no resulta totalmente plana sino que es ligeramente redondeada. Lo mismo se puede afirmar de los laterales, donde no se han eliminado las huellas de la escofina.

Como es habitual la pieza debía estar concebida para ser vista de frente, centrando el escultor su atención en la parte anterior. A juzgar por el nivel de detalle en lo que permite apreciar el estado de conservación, los pliegues que más se veían eran los del frontal y el lateral derecho desde el punto de vista del observador. Pese a su deterioro, debido a su forma, es posible reconocer que el ropaje no estaba asociado al cuerpo de la estatua, sino que parece tratarse de parte de una vestimenta que no pertenecía al tejido adyacente a la anatomía del personaje. Los paños se despliegan en la parte frontal, que es más ancha, y se van estrechando hacia la parte posterior; asimismo se van ensanchando de arriba hacia abajo. Por ello pensamos que se trata del resto de un haz de pliegues, posiblemente perteneciente a la caída del ropaje en un lateral, quizá junto al brazo izquierdo, como se puede ver a menudo en toda clase de estatuas, ideales e icónicas, tanto masculinas como femeninas.

Sin embargo, debido a su estado de conservación es imposible precisar la cronología y tipología de la escultura, e incluso el género del personaje representado. En base a las dimensiones y el material utilizado para su elaboración, frecuente entre las esculturas arquitectónicas, hemos tenido en cuenta, entre otras posibilidades, que se trate de parte de la figura de una Koré siguiendo el modelo del Foro de Augusto en Roma. En ciudades como Augusta Emerita las cariátides se adaptaron como relieves (De la Barrera 2000: 105-110, n. ${ }^{\circ} 371-396$, láms. 126-134), pero en la metrópoli fueron concebidas como esculturas exentas (Goldbeck 2015: 26-28, figs. 14-16 con la bibliografía anterior). Entre los fragmentos de ropajes procedentes de las últimas excavaciones en el 


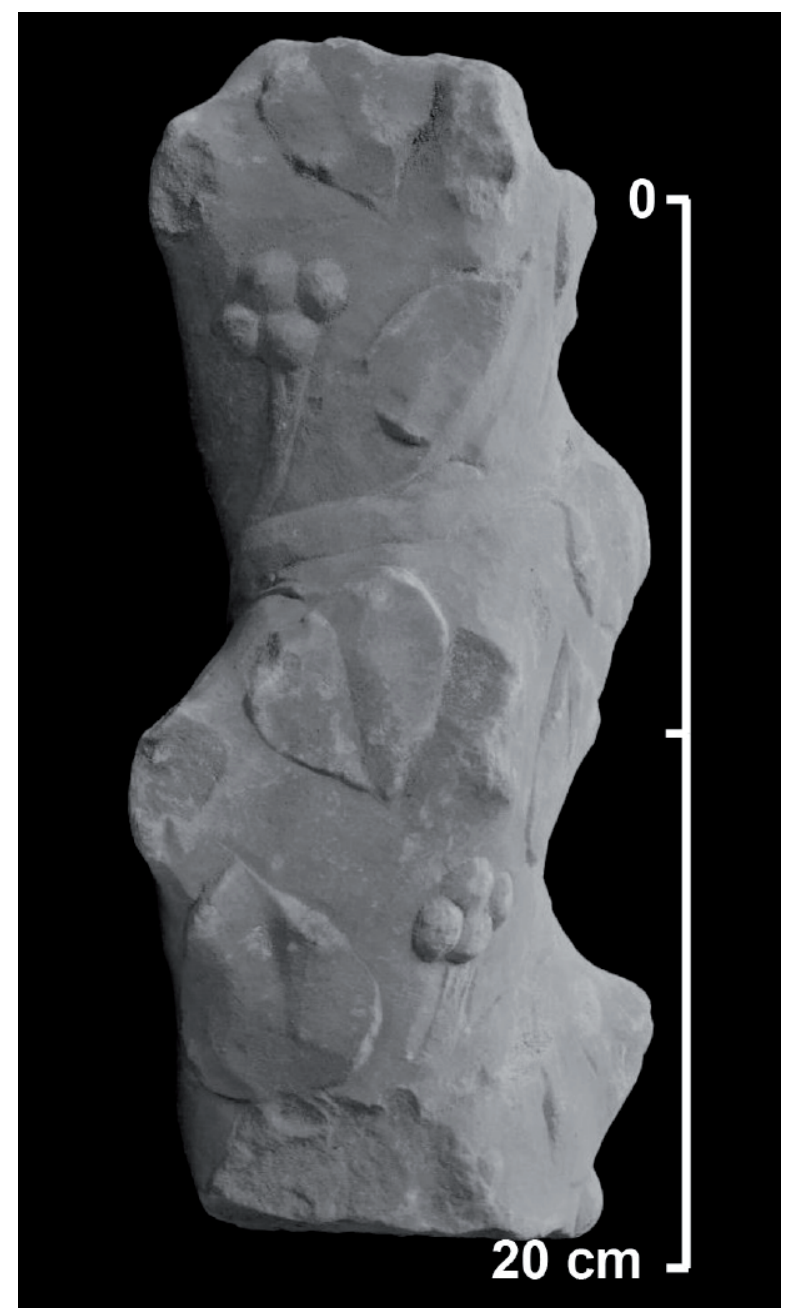

Figura 19. MDT, n. ${ }^{\circ}$ inv. 5498. Elemento escultórico en forma de tronco entorchado.

área del templo al Divus Augustus e interpretados como posibles figuras de cariátides (Macias et al. 2011: 194, fig. 4,1-3, Pensabene y Domingo 2019: 81-82, fig. 34) no se encuentra ninguno similar. Lo más probable es que se trate del fragmento de una figura exenta perteneciente a una estatua erigida en un lugar indeterminado.

19. Fuste o apoyo en forma de tronco de vid con decoración vegetal (fig. 19)

N. ${ }^{\circ}$ inv. 5498. Mármol blanco de grano fino, posiblemente de Luni-Carrara. Altura: $22.5 \mathrm{~cm}$; diámetro: $7.5 \mathrm{~cm}$.

Está roto por sus extremos superior e inferior. La superficie del mármol muestra deterioros de diversa índole.
Inédito

Pequeño elemento cilíndrico entorchado en forma de tronco nudoso de vid, con el nacimiento de tres ramas rotas, que presenta a lo largo de su superficie una decoración con motivos vegetales. Esta consiste principalmente en hojas de hiedra, pero también hay algunas bayas reunidas en grupos de cuatro, colocadas todas ellas a ambos lados de un tallo liso que, siempre con el mismo grosor, asciende en espiral en consonancia con el giro del tronco hacia arriba. Generalmente las hojas están colocadas una enfrente de otra a ambos lados del tallo, si bien a veces una de las hojas se ve sustituida por un grupo de bayas. Toda esta decoración vegetal se halla distribuida de tal forma que deja espacios libres entre los diversos elementos, aunque estos no suelen ser muy amplios.

Cabe la posibilidad, al igual que en otro fragmento procedente del área del foro local de Tarraco (Koppel

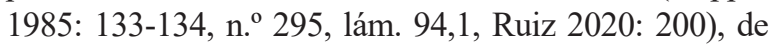
que se trate del apoyo de una estatua de tamaño menor que el natural, siendo probable que representase a Dionysos o uno de sus acompañantes. Personajes del thiasos báquico aparecen frecuentemente junto a apoyos similares (estatua de Baco de la colección Farnese: Capaldi 2009: 133-134, n. ${ }^{\circ}$ 59, lám. LIV, 1-5; fragmento de un grupo de Baco con un sátiro en Cherchel: Landwehr 2006: 1719, n. ${ }^{\circ} 186$, lám. 15). En Cherchel se conservan dos fragmentos similares formalmente a la pieza del MDT, si bien en ambos casos conservan restos de figuras que permiten saber con seguridad que pertenecen a esculturas exentas (Landwehr 2006: 58-59, n. . 213.214, láms. 46.47).

Más probable nos parece que se trate de un elemento de mobiliario decorativo. Los motivos vegetales se hallan esculpidos en bajorrelieve de manera estereotipada, mostrándose casi como un convencionalismo decorativo al igual que aparecen sobre elementos marmóreos de diversa índole (en la parte superior de una crátera en Roma: Rendini 1979: 257-260, n. ${ }^{\circ} 160$, Grassinger 1991: 195-197, n. ${ }^{\circ} 36$, figs. 184-188.213, figs. en texto 37-3; sobre una urna en Nápoles: Sinn 1987: 94, n. ${ }^{\circ} 12$, lám. 6e), entre los que queremos destacar por su forma los vástagos de candelabros (ejemplar completo en el Palacio de los Conservadores: Cain 1985: 176177, n. ${ }^{\circ} 77$, lám. 55,3.4. 57,3. 83,3. 87, lám. adicional 9.12.13; fuste en el Cortile del Belvedere del Museo Vaticano: Cain 1985: 183, n. ${ }^{\circ}$ 95, lám. 88,1).

El labrado y la disposición de los elementos vegetales lo acercan sobre todo al que presentan determinadas columnillas decorativas de fuste cilíndrico, como los ejemplares en Roma (Giuliano -ed.- 1982: 47, n. ${ }^{\circ}$ II 15), 
Vienne (Robert 2003: 186, n. ${ }^{\circ} 439$, lám. 254), de la Villa A de Oplontis (Pensabene 2018: 50, n. ${ }^{\circ}$ 46.47, figs. 43-44), en Girona, de la villa de Els Ametllers (Koppel y Rodà 2008: 126, n. ${ }^{\circ}$ 14, fig. 20, Lamuà 2010: 236, n. $^{\circ}$ 15, fig. 203). Por el contrario, fustes en forma de tronco de árbol envueltos en zarcillos son muy raros. Un ejemplar en el Museo Chiaramonti (Andreae et al. 1995: 46*, láms. 462.463,1.2) presenta una forma y decoración similares, si bien la decoración vegetal no se enrosca girando en torno al tronco. Tan solo hemos podido encontrar dos paralelos a la pieza que nos ocupa. La primera de ellas se encuentra en Roma (de Lachenal 1983: 121-123, n. ${ }^{\circ} 53$, de Angelis 2011) con la bibliografía anterior), si bien se diferencia principalmente en que este muestra una decoración vegetal mucho más rica, trabajada profusamente por medio del trépano, y más claramente relacionada con el mundo báquico dado que en ella aparecen también racimos de uvas y un prótomo con una cabeza de sileno. Lo más semejante al ejemplar del MDT es una columnilla en Karlsruhe procedente de la villa de Voconius Pollio junto a Marino (Breuer 2001: 35-36, n. ${ }^{\circ} 16$, fig. 51).

De la funcionalidad original de estos vástagos con motivos vegetales generalmente no se tiene certeza, en gran parte porque en su mayoría se trata de hallazgos fortuitos. Los autores que se han ocupado de todas estas columnillas también han tenido en cuenta que fuera en origen el apoyo lateral de una estatua, en ocasiones del entorno dionisiaco, aunque debido a que el plano superior está alisado y en comparación con algunos ejemplares de Pompeya, creen más probable que formase parte de un candelabro decorativo o que sirviera para sustentar un herma o una escultura de pequeñas dimensiones que estuviera apoyada sobre ella. El fuste entorchado del Museo Nazionale Romano tiene el plano superior liso y el de Karlsruhe presenta en la parte superior un orificio para un perno, por lo que formaban parte de elementos articulados. Una hipótesis es que fuesen utilizados como elementos decorativos por sí solos, como piezas que contribuyesen a crear un ambiente idílicobucólico en espacios de dispersión (Breuer 2001: 36), como se conoce para fustes similares procedentes con seguridad de ambientes ajardinados en casas de Pompeya, en cuyo caso se conocen como metulae y se combinaban con plantas reales (D'Acunto 2008: 183, n. ${ }^{\circ} \mathrm{D}$ 30-31. También el fuste antes mencionado de la villa de Tossa de Mar procede de un espacio ajardinado con un ninfeo). Debido a la rotura del ejemplar del MDT por ambos extremos, no podemos saber si, como el de Karlsruhe, presentaba en la parte inferior un apéndice cilíndrico destinado a la inserción en un soporte, en cuyo caso se le podría relacionar con una pieza recuperada en el jardín de la domus IX 7, 12 o 14-15 de Pompeya (D'Acunto 2008: 183, n. ${ }^{\circ}$ D 31).

En cuanto a la cronología, los ejemplares más similares a la pieza que nos ocupa han sido datados a principios de la época imperial, particularmente en la primera mitad del siglo I d.C. Debido a la falta de indicios seguros pensamos que puede ser fechado en el siglo I d.C., principalmente debido a la ausencia del uso del trépano. Esta datación se ve avalada por medio de la comparación con ciertos fustes que se encuentran en los almacenes de Villa Adriana, decorados con motivos vegetales similares, aunque destinados al contexto arquitectónico (Márquez 2019: 27, figs. 14-17; 170, n. ${ }^{\circ}$ 119.416, figs. $14.17 ; 171$, n. $^{\circ} 418$, fig. $16 ; 172$, n. $^{\circ} 2373$, fig. 15). En ellos se observa, además de un mayor realce de los elementos vegetales en relación con el fondo del que se destacan, un económico uso de esta herramienta limitado a la estructuración de los motivos de las bayas o a la delimitación de puntos concretos en las hojas.

\section{Fragmento del extremo de un clípeo decorada con meandros (fig. 20)}

$\mathrm{N}^{\circ}$ inv. 11151. Mármol lunense. Altura conservada: 21 $\mathrm{cm}$; anchura conservada: $29.5 \mathrm{~cm}$; profundidad: $5 / 11 \mathrm{~cm}$.

El fragmento está roto por todos sus lados. La cara anterior presenta varios desperfectos.

\section{Inédito}

Fragmento de un clípeo de Júpiter Amón. Ha llegado a nosotros una parte del reborde del clípeo (altura de la greca entrecruzada: $6 \mathrm{~cm}$ ) y del extremo exterior de la corona, en el que se ve la parte más gruesa de un meandro junto a la flor de lis adyacente prácticamente íntegra. Esta particularidad hace que la pieza tenga una cierta relevancia, ya que hasta el momento no se conservaba, al menos en tan buen estado, ninguna flor exterior completa. En uno de los clípeos reconstruidos del MNAT hay dos incompletas (Koppel 1990: 333334.337, lám. 32a, Pensabene 1993: 89-90, n. ${ }^{\circ} 85$; otra flor incompleta se conserva en un fragmento hallado recientemente (Macias et al. 2011: 192, fig. 3,3). El fragmento evidencia que las flores de lis del extremo exterior del clípeo están separadas por amplias superficies lisas al contrario que sus análogas situadas en el interior, junto a la hilera de perlas, donde estas superficies apenas existen. El dorso del clípeo muestra la habitual superficie aplanada y alisada. 

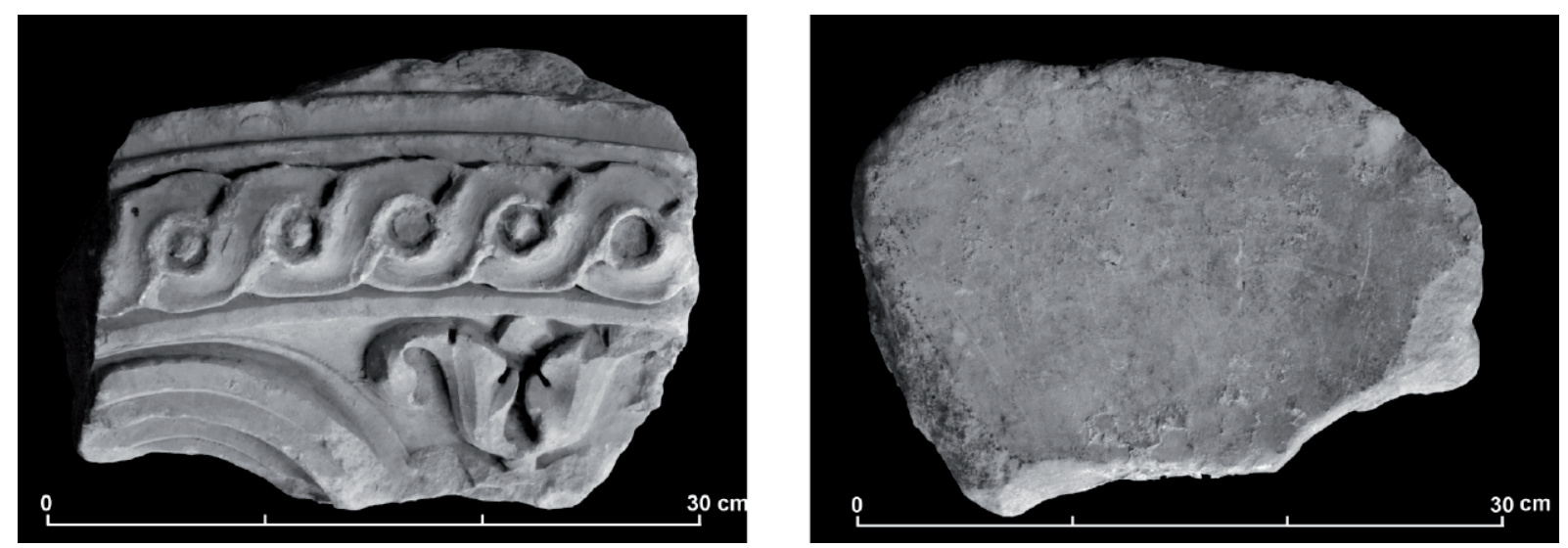

Figura 20. MDT, n. ${ }^{\circ}$ inv. 11151. Fragmento del extremo de un clípeo decorado con meandros.

21. Fragmento de la corona de un clípeo decorada con lengüetas rectilíneas (fig. 21)

N. ${ }^{\circ}$ inv. 6242/6243. Mármol lunense. Altura: $21.5 \mathrm{~cm}$; anchura: $18 \mathrm{~cm}$; profundidad: $13.5 \mathrm{~cm}$.

Está roto en dos pedazos, lo que se produjo con posterioridad a su hallazgo. El fragmento está roto por todos sus lados, aunque en la parte superior presenta una superficie irregular pero de forma curvada, indicio de que fue recortado para su reutilización posterior.

Koppel 1990: 335, nota 42, Pensabene 1993: 93 94, n. ${ }^{\circ} 93$.

Fragmento de la corona de un clípeo con lengüetas rectilíneas, de manera similar a cat. . $^{\circ} 6$ (sobre su tipología, véase lo expresado en dicho lugar). La particularidad más significativa de esta pieza radica en que los bastones centrales de las lengüetas están indicados únicamente de manera somera, sin haber sido finalizados y sin presentar el habitual surco de contorno realizado con el trépano. Esta característica contrasta con el hecho de que las flechas están esculpidas y la delimitación de las lengüetas está realizada. Posiblemente se trata de una pieza inacabada, dado que no se conoce ningún otro fragmento que muestre un trabajo similar. El fragmento conserva la profundidad completa y en el dorso presenta una superficie plana y alisada ininterrumpida.

\subsection{Valoración del conjunto y conclusiones}

Como se desprende del estudio detallado que hemos acometido en estas líneas, los materiales escultóricos conservados en el MDT son de interés para la arqueología romana de Tarragona y aportan nuevos datos, especialmente sobre el programa monumental y decorativo del foro provincial de Tarraco. En su mayoría fueron recuperados en el recinto superior de la ciudad, aunque fuera de su lugar de exposición original y en claro contexto de reutilización. Para los restantes elementos, al menos en su mayoría, se puede suponer que también proceden de esta área, pese a que no tengamos datos suficientes. Esta suposición en ocasiones se ve avalada por la tipología a la que pertenecen los materiales, como es el caso principalmente de los fragmentos de clípeos (cat. n. ${ }^{\circ} 21$ ), pero este criterio no es suficiente para otros como el fragmento de ropaje cat. n. ${ }^{\circ} 17$, si bien, por los datos que tenemos al respecto, es lo más probable. Este fue donado por I. Fortuny que, al mismo tiempo, entregó al museo el fragmento de una cornisa decorada con un motivo de grecas cuadradas entrecruzadas (n. ${ }^{\circ}$ inv. 1630; sin publicar) que puede ser relacionado con otros análogos, la mayor parte de procedencia desconocida (Gimeno 1990: 1511-1512, n. ${ }^{\circ}$ 1982-1984), aunque uno de ellos fue hallado en la acrópolis tarraconense (Gimeno 1990: 1510-1511, n. ${ }^{\circ}$ 1981) y se conservan numerosos fragmentos procedentes de excavaciones emprendidas en la catedral y su entorno en las últimas décadas. Posiblemente las piezas donadas por I. Fortuny fuesen halladas en un mismo punto, quizá del área de la catedral.

En cuanto a la cronología, de acuerdo con los estudios sobre la decoración arquitectónica del foro provincial de Tarraco, la mayor parte de las piezas estudiadas pueden datarse en la época flavia, por lo que se pueden adscribir a la reforma del templo y su pórtico en el reinado de Vespasiano. Esta afirmación es válida principalmente para los fragmentos de clípeos (cat. n. ${ }^{\circ} 2-9$, 12-14, 20, 21 y posiblemente cat. n. $\left.{ }^{\circ} 15\right)$, y también para el trozo de relieve con candelabro (cat. n. ${ }^{\circ} 10$ ). 

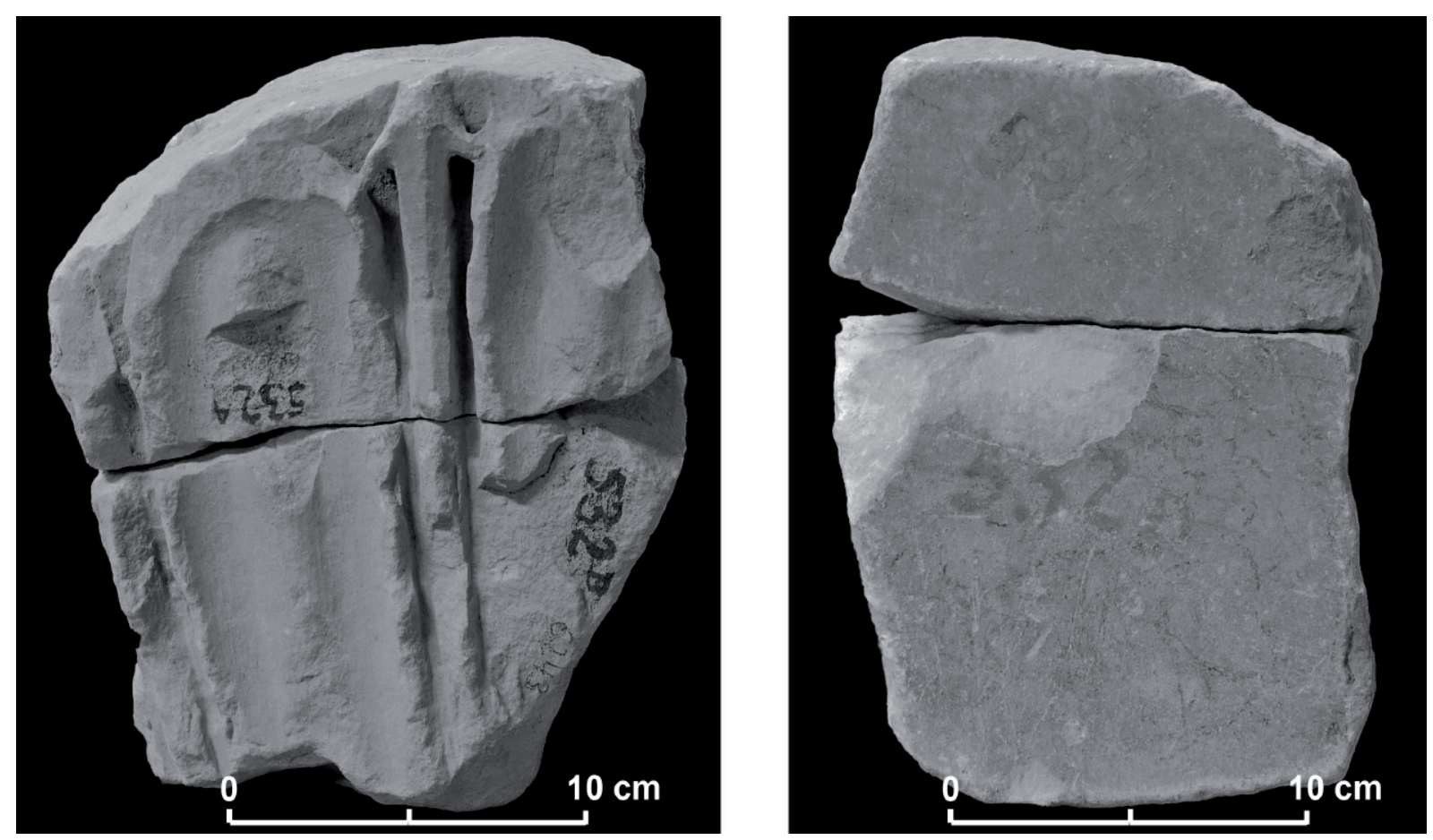

Figura 21. MDT, n. ${ }^{\circ}$ inv. 6242/6243. Fragmento de la corona de un clípeo decorado con lengüetas rectilíneas.

El relieve de armas (cat. n. ${ }^{\circ}$ 16) pudiera datarse a finales del siglo I o inicios de la siguiente centuria, en tanto que el posible remate de imbrex con prótomo de león (cat. n. ${ }^{\circ} 11$ ) y el tronco (cat. n. ${ }^{\circ} 19$ ) se datan con bastante probabilidad en el siglo I d.C. Las restantes esculturas (cat. n. ${ }^{\circ} 1,17$ y 18 ), debido a su estado fragmentado, tan solo admiten una posible datación en el periodo altoimperial. Podrían adscribirse a cualquiera de las fases propuestas para el templo del divus Augus$t u s$, ya sean la tiberiana, la flavia o la adrianea, o pudieron haber pertenecido a esculturas erigidas en este lugar en momentos distintos.

En lo referente a las materias primas lapídeas, con la única excepción de un fragmento de ropaje en mármol blanco de grano fino-medio posiblemente de Paros (cat. n. ${ }^{\circ}$ 17), los restantes elementos están realizados en mármol blanco de grano fino de escasa translucidez, frecuentemente con vetas grisáceas, de idénticas características en todos ellos. Pese a la falta de datos analíticos, estos rasgos permiten aproximar este material a los procedentes de Luni-Carrara, opinión tradicionalmente extendida a partir de la observación macroscópica para la mayor parte de los materiales arquitectónicos del foro provincial, incluyendo los relieves (Pensabene 1993: passim). Esta hipótesis se ve avalada en el estudio realizado hace algunos años sobre algunas piezas recuperadas en las excavaciones de la catedral (Àlvarez et al. 2012), cuyas analíticas arqueométricas permitieron confirmar que los relieves arquitectónicos fueron elaborados en mármol lunense, destacando los fragmentos de clípeos y de candelabros vegetales (Àlvarez et al. 2012: 201, figs. 4,1.2 y 6).

Por lo que respecta a sus tipologías, entre las piezas romanas del MDT las esculturas exentas son prácticamente inexistentes, estando solamente representadas por medio de dos fragmentos de ropajes (cat. n. ${ }^{\circ} 17 \mathrm{y}$ 18) cuyos lugares de hallazgo concretos además se desconocen, por lo que apenas aportan información sobre tipo y cronología de las estatuas a los que pertenecieron. Lo único que podemos afirmar con seguridad es que no pertenecieron a una misma figura, ya que están realizados en mármoles distintos. Mucho más abundantes y mejor conservados son los relieves arquitectónicos, entre los que se encuentran los que están decorados con motivos vegetales, a los que dedicaremos un estudio específico (Ruiz, en prensa: fig. 2). Entre ellos destaca el fragmento del tallo de un roleo de orden gigante, perteneciente a una tipología muy bien documentada en Tarraco y que, por sus características, se ha atribuido al propio edificio templar (Gimeno 1990: 1175-1182, n. ${ }^{\circ}$ 1566-1572, Pensabene 1993: 80-82, n. ${ }^{\circ} 78$, Pensabene y Mar 2004: 78-80, n. ${ }^{\circ}$, figs. 3.5, Pensabene 2005: 
236-237, n. ${ }^{\circ}$ 1, láms. 3-4, figs. 5.6.8, Pensabene y Mar 2010: 255-262, figs. 8.12, Pensabene y Domingo 2019: 66, n. $^{\circ} 1$, fig. 11). Este ejemplar fue recuperado en el solar del antiguo matadero, donde también salió a la luz el fragmento exiguo de una lastra decorada con un candelabro en relieve (cat. n. ${ }^{\circ}$ 10). Debido a su estado de conservación, el valor de este conjunto de ejemplares no radica evidentemente en la información que aportan para la reconstrucción de ambos elementos, sino en que permiten añadir nuevas evidencias a dos conjuntos de relieves arquitectónicos bien conocidos en el programa monumental del área del templo al divus Augustus, y documentan la dispersión de materiales por todo el casco antiguo de la ciudad, además del interesante dato sobre su procedencia. Asimismo, no podemos descartar absolutamente la posibilidad de que algunos fragmentos con kyma lésbico conservados en el MDT pertenecieran a los conjuntos de frisos con roleos, o a los relieves con guirnaldas, bucráneos y elementos sacerdotales de época flavia (Gimeno 1990: 1204-1215, n. ${ }^{\circ} 1588-1602$, Pensabene 1993: 83-87, n. ${ }^{\circ} 80.81$, Pensabene y Mar 2004: 80-83, n. ${ }^{\circ} 2$, figs. 4-6, Pensabene 2005: 237-239, figs. 7-9, Pensabene y Mar 2010: 255, 258, 262-265, figs. 9.11.13, Pensabene y Domingo 2019: fig. 35), en ambos casos enmarcados en sus extremos superior e inferior por cimacios lésbicos de diversa forma, si bien en ningún caso hemos detectado ningún indicio que permita asegurarlo, por lo que hemos prescindido de ellos en nuestro estudio.

De mayor interés resulta la publicación de algunas piezas inéditas que se pueden definir como elementos escultóricos de carácter ornamental. Se trata de una pata felina perteneciente con bastante probabilidad a un elemento de mobiliario (cat. n. ${ }^{\circ}$ 1) y de un fuste de forma entorchada decorado con motivos vegetales en relieve (cat. n. $\left.{ }^{\circ} 19\right)$, en el que se puede entrever una relación con el contexto báquico. Esta clase de ejemplares, como es sabido, es más propia de ambientes domésticos, si bien no se puede descartar su procedencia de contextos públicos de carácter oficial. Del propio foro provincial de Tarraco proceden diversos recipientes marmóreos decorados con máscaras dionisiacas (Koppel y Rodà 1996: 141-147, figs. 5-10), que han llevado a plantear la existencia de espacios de esparcimiento, documentados en esta área por medio de excavaciones arqueológicas que han constatado que el complejo forense disponía de zonas ajardinadas (Pensabene y Domingo 2019: 50-51). Más dudosa resulta la procedencia original de dos estatuillas de erotes halladas en un punto cercano al casco antiguo de Tarragona (Ruiz 2019).
La mayor parte de los elementos escultóricos romanos que se encuentran en el MDT corresponden a fragmentos diversos de clípeos, que conforman el conjunto más importante desde el punto de vista numérico, y en los que prácticamente todas las tipologías conocidas de estos relieves se hallan representadas. Entre ellos se encuentran principalmente fragmentos de coronas o de la decoración perimetral, si bien también han llegado a nosotros vestigios exiguos de los emblemata centrales y superficies considerables de la lastra cuadrangular exterior sin decoración en la que se insertaban los tondi. El hecho de que se trate a menudo de piezas demasiado fragmentadas dificulta su comprensión, especialmente en aquellas que presentan particularidades no existentes en ejemplares más completos. Esta afirmación es válida principalmente en los que conservan restos de prótomos centrales (cat. n. ${ }^{\circ} 13$ y 14). Se trata de una dificultad que puede achacarse a las condiciones de conservación de estas piezas desde la Antigüedad, pero con bastante seguridad se vería paliada en un análisis global de los fragmentos de clípeos que estamos acometiendo en la actualidad. El estudio de los ejemplares del MDT nos ha brindado la oportunidad de trabajar de manera directa con estos materiales, permitiendo documentar de manera sistemática detalles que se nos escapan en los clípeos del MNAT, que son los más conocidos en la bibliografía y que por haber estado expuestos a una considerable altura y anclados en la pared, ha quedado dificultada una autopsia más detallada.

Asimismo, el estudio de estos ejemplares nos parece de interés dado que en la actualidad continúan existiendo algunas cuestiones que no han sido totalmente resueltas. Una de las más significativas es la relación entre máscaras centrales y tipo de la decoración perimetral. Lo único seguro al respecto es que las máscaras con representación de Júpiter Amón se hallaban enmarcadas por meandros que encierran un bastón del que surge una flor de lis. Por lo que respecta a los ejemplares con lengüetas, la única propuesta es la de E.M. Koppel, quien piensa que los emblemas de Medusa se hallaban rodeados por lengüetas rectas, relacionando los de lengüetas curvilíneas con una supuesta tercera divinidad masculina (Koppel 1990: 336 con nota 47). La autora basa su hipótesis en la circunstancia de que en la calle Portal del Carro fue hallado un trozo de clípeo de esta tipología junto con un fragmento de máscara barbada, que muestra algunas diferencias con respecto a los prótomos conocidos de Júpiter Amón (Koppel 1990: 335-336, lám. 32d, Pensabene 1993: 92, n. ${ }^{\circ} 88$, Goldbeck 2015: 90, fig. 130). Esta última propuesta ha tenido una escasa aceptación, 
puesto que posteriormente otros investigadores han negado esta interpretación, reconociendo en dicho fragmento una representación más de esta misma divinidad sincrética (Goldbeck 2015: 90). Por nuestra parte, podemos afirmar con seguridad que la teoría de Koppel en cuanto a la relación de las máscaras de Medusa con las coronas decoradas con lengüetas rectilíneas parece ser la correcta. Así lo corroboran fragmentos que conservan partes tanto de la máscara como de la corona, como el hallado recientemente en las excavaciones de la catedral (Macias et al. 2007: 779, fig. 6,3, Macias et al. 2011: 192, fig. 3,5, Macias et al. 2012: 32, n. ${ }^{\circ}$ 1.2.14, Peña 2018: 173, fig. 4b), al que se añaden dos de los ejemplares que aquí estudiamos (cat. n. ${ }^{\circ} 13$ y 14).

Algunos fragmentos de clípeos conservan partes importantes de la superficie exterior desprovista de decoración (cat. n. 5 y 7), lo que nos proporciona la evidencia de que las piezas eran en realidad originalmente lastras de forma cuadrangular en las que se encontraban insertos los tondi. Esta peculiaridad se observa en dos fragmentos conservados en el MNAT: uno cuya corona exterior está decorada con meandros y por lo tanto perteneciente a un prótomo de Júpiter Amón (Gimeno 1990: 1282, n. ${ }^{\circ}$ 1686) y el segundo decorado con lengüetas curvilíneas (Gimeno 1990: 1287, n. ${ }^{\circ} 1704$, Pensabene 1993: 92, n. ${ }^{\circ}$ 89). Los ejemplares del MDT conservan el canto exterior de superficie lisa, lo que posibilita la reconstrucción precisa de la forma original de la lastra. En el aspecto técnico, queremos destacar la circunstancia de que dos ejemplares presentan en el dorso, sobre la superficie lisa, franjas de trazado rectilíneo que tal vez ponen de manifiesto el sistema de anclaje y que pudieran informarnos sobre la orientación de estos fragmentos en relación a la totalidad de los clípeos (cat. n. ${ }^{\circ} 2$ y 13). Debido a esta misma particularidad pueden ser relacionados con algunos fragmentos recuperados en las últimas excavaciones de la catedral.

En cuanto a las áreas de hallazgo, resulta claro, especialmente entre los ejemplares hallados en 1898, que se encontraban en contexto de reutilización, dado que en la zona de la Plaza de l'Escorxador no se extendía el foro provincial. Algunos muestran evidencias de haber sido cortados y troceados de antiguo: a un fragmento de clípeo (cat. n. ${ }^{\circ}$ ) se le recortó de manera intencional el prótomo, como probablemente también a otro (cat. n. ${ }^{\circ}$ ); un segundo fragmento (cat. n. ${ }^{\circ} 6$ ) fue recortado para obtener un elemento de menores dimensiones y de una forma diversa a la original. Dos fragmentos, pertenecientes respectivamente a un relieve con candelabro (cat. n. ${ }^{\circ}$ 10) y un friso de roleos vegetales (Ruiz, en prensa), que corresponden ambos a series muy bien conocidas, se hallan tan fragmentados que resulta muy difícil reconocerlos. Todos ellos proporcionan la evidencia de que los materiales hallados en esta área son resultado del desmonte de los elementos arquitectóni$\cos$ y decorativos del foro provincial, lo que permite relacionarlos con una zona de reciclado de mármoles, documentada ya con anterioridad en el área adyacente (Arola et al. 2012). Como ya observaron previamente otros investigadores (Serra 1960: 82, Hauschild 1992: 111), similar debe ser el caso de los materiales hallados en 1933 en el jardín de Santa Tecla la Vella, que, al mostrar claros indicios de haber sido retallados y reelaborados, ponen de manifiesto que nos hallamos ante los restos de un depósito de elementos en mármol, acopiados para su reciclado en épocas posteriores en paralelo a la transformación de la zona a partir del periodo tardoantiguo (Macias et al. 2009: 453-456). El único elemento discordante es que algunos ejemplares, principalmente fragmentos de clípeos, no están finalizados, por lo que es posible que se trate de desechos de talla.

Por último, de algunos otros ejemplares se desconocen los lugares precisos donde fueron hallados, aunque se consideran mayoritariamente procedentes de la catedral y su entorno, quizá como consecuencia de las diversas obras emprendidas fundamentalmente en el siglo XX o quizá con anterioridad. La tipología de ciertas piezas no excluye esta posibilidad, siendo el ejemplo más claro el de los fragmentos de clípeos (cat. n. ${ }^{\circ} 20$ y 21), siendo imposible determinar las circunstancias de hallazgo precisas de las restantes, que, como hemos podido comprobar, presentan determinadas peculiaridades de interés (cat. n. ${ }^{\circ} 17,18$ y 19).

\section{Agradecimientos}

Este artículo forma parte de la tesis doctoral del autor, realizada gracias al programa FPU del Ministerio de Universidades del Gobierno español (FPU2016/00675). También se inserta en el proyecto Corpus Signorum Imperii Romani - Països Catalans del Institut d'Estudis Catalans (PRO2019-S01-ARASA), del que forma parte el estudio de las esculturas romanas, exentas y en relieve, procedentes de Tarragona, en el marco de la redacción en curso de un fascículo del CSIR dedicado a esta ciudad.

Quiero expresar mi agradecimiento por su ayuda a Joaquín Ruiz de Arbulo y Diana Gorostidi (Universidad Rovira i Virgili / Institut Català d'Arqueologia Clàssica), directores de esta tesis. El estudio autóptico de los materiales del Museo Diocesano ha sido posible gracias a un convenio firmado entre esta institución y 
el ICAC. Deseo agradecer a Sofía Mata, directora de este museo, su inestimable ayuda, la información facilitada sobre las piezas y las facilidades concedidas para realizar su estudio. Un especial reconocimiento quiero expresar a Antonio Peña (Universidad Autónoma de Barcelona / Institut Català d'Arqueologia Clàssica), buen conocedor de estos materiales, por la revisión del manuscrito así como por sus valiosos comentarios y sugerencias, además de por haberme permitido consultar el manuscrito de su artículo en prensa sobre la decoración del ático del pórtico del templo al divus $\mathrm{Au}$ gustus (Peña, en prensa). Por último, agradezco a los revisores anónimos externos sus observaciones, que han contribuido en gran medida a enriquecer este trabajo. Todas las imágenes pertenecen al archivo fotográfico del autor.

\section{BIBLIOGRAFÍA}

Alföldy, G. (2002): “In omnes provincias exemplum: Hispanien und das Imperium Romanum", en G. Urso (ed.), Hispania terris omnibus felicior. Premesse ed esiti di un proceso di integrazione. Atti del convegno internazionale: 183-199. Cividale del Friuli (2001), Pisa, Fondazione Niccolò Canussio.

Alföldy, G. (2014): "Hadrians Besuch in Tarraco (HA, H 12,3-5)", en C. Bertrand-Cagenbach y F. Chausson, F. (eds.), Historiae Augustae Colloquium Nanceiense. Atti dei Convegni sulla Historia Augusta XII: 11-29. Nancy (2010), Bari, Edipuglia.

Àlvarez, A.; Macias, J. M.; Muñoz, A.; Pitarch, À.; Teixell, I. y Menchon, J. J. (2012): “The marmora used in the imperial cult area of Tarraco (Hispania Citerior)", en A. Gutiérrez, P. Lapuente e I. Rodà (eds.), Interdisciplinary Studies on Ancient Stone. Proceedings of the IX Association for the Study of Marbles and Other Stones in Antiquity (ASMOSIA) Conference: 196-203. Tarragona (2009), Tarragona, Institut Català d'Arqueologia Clàssica.

Andreae, B.; Anger, K.; De Angelis, M. A.; Geominy, W.; Granino, M. G.; Köhler, J.; Kreeb, M.; Liverani, P.; Mathea-Förtsch, M.; Stadler, M. y Uncini, A. (1995): Bildkatalog der Skulpturen des Vatikanischen Museums I. Museo Chiaramonti. BerlínNueva York, De Gruyter.

Arola, R.; Domingo, J. Á. y Gasull, N. (2012): "The imported marmora from the Jaume I School: an assemblage from the Provincial Forum of Tarraco", en A. Gutiérrez, P. Lapuente e I. Rodà (eds.), Interdisciplinary Studies on Ancient Stone.
Proceedings of the IX Association for the Study of Marbles and Other Stones in Antiquity (ASMOSIA) Conference: 190-195. Tarragona (2009), Tarragona, Institut Català d'Arqueologia Clàssica.

Bonanome, D. (2013): "Grande bacino figurato", en Gasparri, C. y Paris, R. (eds.) (2013): Palazzo Massimo alle Terme. Le collezioni: 126-127, $\mathrm{n}{ }^{\circ}$ 69. Milano, Electa.

Breuer, Ch. (2001): Antike Skulpturen. Bestandskatalog des Badischen Landesmuseums Karlsruhe. Karlsruhe, Badisches Landesmuseums Karlsruhe.

Cain, H.-U. (1985): Römische Marmorkandelaber. Mainz am Rhein, Von Zabern.

Capaldi, C. (2009): "Statua di Dioniso", en Gasparri, C. (ed.) (2009): Le sculture Farnese I. Le sculture ideali: 133-134. Milano, Electa.

CIL II ${ }^{2} / 14.3$ = Alföldy, G. (2012): Corpus Inscriptionum Latinarum. Inscriptiones Hispaniae Latinae, editio altera. Pars XIV, conventus Tarraconensis pars meridionalis. Fasc. 3, Colonia Iulia Urbs Triumphalis Tarraco. Berlín-Nueva York, De Gruyter.

Claveria, M. (2001): Corpus Signorum Imperii Romani - España I 1. Los sarcófagos romanos de Cataluña. Murcia, Tabularium.

Cohon, R. H. (1984): Greek and Roman Stone table supports with decorative reliefs, Tesis Doctoral, New York University. Inédita.

D'Acunto, L. A. (2008): "Regio IX", en A. Carrella, L. A. D'Acunto, N. Inserra y C. Serpe, Marmora Pompeiana nel Museo Archeologico Nazionale di Napoli. Gli arredi scultorei delle case pompeiane: 155-203. Roma, «L'Erma» di Bretschneider.

De Angelis, M. (2011): "Colonnina tortile", en Candilio, D.; Capodiferro, A.; Cenci, C.; Clarrocchi, B.; De Angelis, M.; Fabiani, A. G.; Fortuna, D.; Giobbe, Ch.; Palma, B.; Signani, L.; Sist Russo, L.: Violante, S. y Vordemann, St. D. (2011): Palazzo Altemps. Le collezioni: 210. Milano, Electa.

De la Barrera, J. L. (2000): La decoración arquitectónica de los foros de Augusta Emerita. Roma, «L'Erma» di Bretschneider.

De Lachenal, L. (1983): “Colonnina tortile con motivi bacchici”, en Giuliano (ed.), Museo Nazionale Romano I. Le Sculture 5, I Marmi Ludovisi nel Museo Nazionale Romano: 121-123. Roma, De Luca.

Domingo, J. Á. (2005): Capitells corintis a la provincia tarraconense (S. I-III dC). Tarragona, Arola.

Domingo, J. Á. (2019): "Elements de decoració arquitectónica procedents de les excavacions del 1919”, en J. A. Remolà (ed.), Troballes arqueològiques al teatre romà de Tarragona. Diari de Francesc 
Carbó (1919): 79-102. Tarragona, Museu Nacional Arqueològic de Tarragona - Agència Catalana de Patrimoni Cultural - Departament de Cultura de la Generalitat de Catalunya.

Domingo, J. Á.; Bravo, P.; Díaz, M.; Fabregat, R.; Menchon, J. y Roig, J. F. (2019): "Nuevos elementos de escultura arquitectónica hallados en Tarragona", en J. López (ed.), Tarraco Biennal. Actes $4 t$ Congrés Internacional d'Arqueologia i Món Antic. VII Reunió d'Arqueologia Cristiana Hispànica. El cristianisme en l'Antiguitat Tardana: Noves perspectives: 105-116. Tarragona (2018), Tarragona, Universitat Rovira i Virgili - Institut d'Estudis Catalans.

Fishwick, D. (2002): The Imperial Cult in the Latin West. Studies in the Ruler Cult of the Western Provinces of the Roman Empire. III: Provincial Cult. Part 2: The Provincial Priesthood. Leiden - Boston - Colonia, Brill.

Fishwick, D. (2017): Precint, Temple and Altar in Roman Spain. Studies on the Imperial Monuments at Mérida and Tarragona. Surrey - Burglington, Ashgate.

Fortuny, K. y Ruiz, J. C. (en prensa): "El conjunto tardoantiguo de la Plaza d'en Rovellat de Tarragona: del análisis arquitectónico al estudio de los elementos marmóreos altoimperiales hallados en contexto secundario", en Exemplum et Spolia. La reutilización arquitectónica en la transformación del paisaje urbano en las ciudades históricas.

Gimeno, J. (1990): Estudios de arquitectura y urbanismo en las ciudades romanas del nordeste de Hispania. Tesis Doctoral, Universidad Complutense de Madrid. Inédita.

Giuliano, A. (ed.) (1979-1995): Museo Nazionale Romano I. Le Sculture 1-12. Roma, De Luca.

Goldbeck, V. (2015): Fora augusta. Das Augustusforum und seine Rezeption im Westen des Imperium Romanum. Regensburg, Schnell \& Steiner.

Grassinger, D. (1991): Römische Marmorkratere. Mainz am Rhein, Von Zabern.

Hauschild, Th. (1992): "Los hallazgos romanos de mármol en la parte alta de Tarragona”. Butlleti Arqueològic 14: 107-135.

Hermary, A.; Lauxerois, R. (2003): "Pieds de siège sculptés", en Terrer, D.; Lauxerois, R.; Robert, R.; Gaggadis-Robin, V.; Hermary, A.; Jockey, Ph. y Lavagne, H.: Nouvel Espérandieu. Recueil général des sculptures sur pierre de la Gaule I. Vienne (Isère): 188-190. París, Académie des Inscriptions et Belles-Lettres.

Jockey, Ph. (2003): "Serre d'aigle", en Terrer, D.; Lauxerois, R.; Robert, R.; Gaggadis-Robin, V.;
Hermary, A.; Jockey, Ph. y Lavagne, H.: Nouvel Espérandieu. Recueil général des sculptures sur pierre de la Gaule I. Vienne (Isère): 199. París, Académie des Inscriptions et Belles-Lettres.

Koppel, E. M. (1985): Die römischen Skulpturen von Tarraco. Berlin, De Gruyter.

Koppel, E. M. (1990): "Relieves arquitectónicos de Tarragona”, en W. Trillmich y P. Zanker (eds.), Stadtbild und Ideologie. Die Monumentalisierung hispanischer Städte zwischen Republik und Kaiserzeit: 327-340. Munich, Bayerischen Akademie der Wissenschaften.

Koppel, E. M. y Rodà, I. (2008): "La escultura de las villae de la zona del noreste hispánico: los ejemplos de Tarragona y Tossa de Mar”, en C. Fernández, V. García-Entero y F. Gil (eds.), Las villae tardorromanas en el occidente del Imperio: Arquitectura y función. IV Coloquio Internacional de Arqueología en Gijón: 99-131. Gijón (2006), Gijón, Trea.

Krauskopf, I. (1988): s. v. Gorgo, Gorgones, en Lexicon Iconographicum Mythologiae Classicae, Band IV (1988): 285-330. Zürich - Munich - Düsseldorf: Artemis.

Landwehr, Chr. (2006): Die römische Skulpturen von Caesarea Mauretaniae III. Idealplastik. Bacchus und Gefolge, Masken, Fabelwesen, Tiere, Bukranien, Nicht benennbare Figuren. Mainz am Rhein, Von Zabern.

Lamuà, M. (2010): "Les escultures", en L. Palahí y J.M. Nolla, Felix Turissa. La vil.la romana dels Ametllers $i$ el seu fundus (Tossa de Mar, la Selva): 229244. Tarragona, Departament de Cultura i Mitjans de Comunicació de la Generalitat de Catalunya Ajuntament de Tossa de Mar - Institut d'Estudis Catalans - Institut Català d'Arqueologia Clàssica.

Lejars, Th. (2007): "Caractères originaux de l'armement celtique. Contraintes idéologiques et choix techniques", en P. Sauzeau y Th. Van Compernolle (eds.), Les armes dans l'Antiquité. De la technique à l'imaginaire: 145-182. Montpellier, Presses Universitaires de la Méditerranée.

Lemoine, Y. (2013): Nouvel Espérandieu. Recueil général des sculptures sur pierre de la Gaule IV. Fréjus. París, Académie des Inscriptions et BellesLettres.

León, P. (2015): "Nuevas consideraciones sobre los relieves del Templo de Marte en Mérida", en J. García, I. Mañas y F. Salcedo (eds.), Navigare necesse est. Estudios en homenaje a José María Luzón Nogué: 499-507. Madrid, Universidad Complutense de Madrid. 
León, P. y Vargas, S. (2018): "Escultura ideal”, en P. León y T. Nogales (eds.), Villa Adriana. Escultura de los almacenes: 29-120. Roma, «L'Erma» di Bretschneider.

Macias, J. M.; Menchon, J. J.; Muñoz, A. y Teixell, I. (2007): "Excavaciones en la catedral de Tarragona y su entorno: avances y retrocesos en la investigación sobre el Culto Imperial", en T. Nogales y J. González (ed.), Culto Imperial: politica y poder: 764-787. Roma, «L'Erma» di Bretschneider.

Macias, J. M.; Fiz, I.; Piñol, Ll.; Miró, M. T. y Guitart, J. (dirs.) (2007): Planimetria Arqueològica de Tàrraco. Tarragona, Departament de Cultura i Mitjans de la Comunicació de la Generalitat de Catalunya - Ajuntament de Tarragona - Conselleria de Patrimoni - Institut Català d'Arqueologia Clàssica.

Macias, J. M.; Menchon, J. J.; Muñoz, A. y Teixell, I. (2009): "La construcción del recinto imperial de Tarraco (provincia Hispania Citerior)", en J. López y Ò. Martín (eds.), Tarraco: construcció $i$ arquitectura d'una capital provincial romana. Actes del Congrès internacional en homenatge a Theodor Hauschild I. Butlletí Arqueolòic 32: 423-479. Tarragona (2009), Tarragona, Reial Societat Arqueològica Tarraconense.

Macias, J. M.; Muñoz, A.; Teixell, I. y Menchon, J. J. (2011): "Nuevos elementos escultóricos del recinto de culto del Concilium Provinciae Hispaniae Citerioris (Tarraco, Hispania Citerior)", en T. Nogales e I. Rodà (eds.), Roma y las provincias: modelo y difusión II: 873-886. Roma, «L'Erma» di Bretschneider.

Macias, J. M.; Muñoz, A.; Peña, A.; Ramon, M. y Teixell, I. (2012): Praesidium, Templum et Ecclesia. Les intervencions arqueologiques a la Catedral de Tarragona 2010-2011. Memòria d'una exposició temporal. Tarragona, Sugrañes.

Macias, J. M.; Muñoz, A.; Peña, A. y Teixell, I. (2014): "El templo de Augusto en Tarraco: Últimas excavaciones y hallazgos", en J. M. Àlvarez, T. Nogales e I. Rodà (eds.), Actas XVIII Congreso Internacional de Arqueología Clásica. Centro y Periferia en el Mundo Clásico II: 1539-1543. Mérida (2013), Mérida, Museo Nacional de Arte Romano.

Mar, R. (1993): "El recinto de culto imperial de Tárraco y la arquitectura flavia", en R. Mar (ed.), Els monuments provincials de Tarraco. Noves aportacions al seu coneixement: 107-156. Tarragona, Universitat Rovira i Virgili.

Mar, R.; Ruiz de Arbulo, J.; Vivó, D. y Beltrán-Caballero, J. A. (2012): Tarraco. Arquitectura y urbanismo de una capital provincial romana, I: De la Tarragona ibérica a la construcción del templo de Augusto. Tarragona, Universitat Rovira i Virgili. Mar, R.; Ruiz de Arbulo, J.; Vivó, D.; Beltrán-Caballero, J. A. y Gris, F. (2015): Tarraco. Arquitectura y urbanismo de una capital provincial romana, II: La ciudad imperial. Tarragona, Universitat Rovira i Virgili.

Márquez, C. (2019): La decoración arquitectónica de Villa Adriana (Material selecto de los almacenes). Córdoba, Universidad de Córdoba.

Moss, Ch. Fr. (1989): Roman Marble Tables. Tesis doctoral, Princeton University. Inédita.

Nogales, Tr. (2011): “Imperialismo romano: Iconografía al servicio del poder. Modelos romanos, provinciales y de Augusta Emerita". Madrider Mitteilungen 52: 411-439.

Nogales, Tr. (2017): "I Rilievi della congeries armorum del teatro di Augusta Emerita", en Parisi Presicce, C.; Milella, M.; Pastor, S. y Ungaro, L. (eds.) (2017): Traiano. Costruire l'Impero, Creare l'Europa: 461, Roma, De Luca.

Nogales, Tr. (2018): "Escultura ornamental", en P. León y T. Nogales (eds.), Villa Adriana. Escultura de los almacenes: 121-245. Roma, «L'Erma» di Bretschneider.

Paoletti, O. (1988): s. v. Gorgones Romanae, en Lexicon Iconographicum Mythologiae Classicae, Band IV (1988): 345-362. Zürich - Munich - Düsseldorf: Artemis.

Paris, R. (1979): "Tazza neoattica", en Giuliano, A. (ed.), Museo Nazionale Romano I. Le sculture 1: 255-257. Roma, De Luca.

Pensabene, P. (1993): "La decorazione architettonica dei monumenti provinciali di Tarraco", en R. Mar (ed.), Els monuments provincials de Tarraco. Noves aportacions al seu coneixement: 25-105. Tarragona, Universitat Rovira i Virgili.

Pensabene, P. (2005): "Nuovi ritrovamenti di fregi marmorei dall'acropoli di Tarraco e i complessi monumentali di culto imperiale", en X. Lafon y G. Sauron (eds.), Théorie et pratique de l'architecture romaine. Études offertes à Pierre Gros: 233-246. Aix-en-Provence, Université de Provence.

Pensabene, P. (2018): "Villa A di Oplontis: elementi della decorazione architettonica in marmo". Rivista di Studi Pompeiani 29: 45-85. DOI: 10.1400/267294.

Pensabene, P. y Domingo, J. Á. (2019): "El Concilium Provinciae Hispaniae Citerioris (CPHC): una lectura arquitectónica a la luz de los nuevos datos y de los conjuntos imperiales de Roma”. Butlleti Arqueològic 41: 41-126. 
Pensabene, P. y Mar, R. (2004): "Dos frisos marmóreos en la Acrópolis de Tarraco, el templo de Augusto y el complejo provincial de culto imperial", en J. Ruiz de Arbulo (ed.), Simulacra Romae. Roma y las capitales provinciales del Occidente europeo: Estudios Arqueológicos: 73-86. Tarragona (2002), Tarragona, El Médol.

Pensabene, P. y Mar, R. (2010): "Il tempio di Augusto a Tarraco. Gigantismo e marmo lunense nei luoghi di culto imperiale in Hispania e Gallia". Archeologia Classica 61: 243-307. DOI: 10.1400/173288.

Peña, A. (2018): "El pórtico del recinto de culto a Divus Augustus en la acrópolis de Tarraco: la decoración del ático y su reflejo en las ciudades romanas de la Galia”. Zephyrus 82: 167-185. DOI: http://dx.doi. org/10.14201/zephyrus201882167185.

Peña, A. (2020): "Nuevamente sobre la decoración del ático del pórtico del recinto de culto a Divo Augusto en la acrópolis de Tarraco". Butlletí Arqueologic 42.

Peña, A.; Gorostidi, D.; Macias, J. M.; Muñoz, A.; Rodà, I. y Teixell, I. (2015): "Más datos sobre el templo del Divus Augustus de Tarraco: a propósito de una nueva inscripción”, en J. López (ed.), Tarraco Biennal. Actes 2on Congrés Internacional d'Arqueologia i Món Antic. August i les províncies occidentals: 2000 aniversari de la mort d'August: 181-189. Tarragona (2014), Tarragona, Fundació Privada Mútua Catalana.

Polito, E. (1998): Fulgentibus armis. Introduzione allo studio dei fregi d'armi antichi. Roma, «L'Erma» di Bretschneider.

Rapin, A. (1999): “L'armement celtique en Europe: chronologie de son evolution technologique du $\mathrm{V}^{\mathrm{e}}$ au $1^{\text {er }}$ s. av. J-C.". Gladius 19: 33-67.

Rendini, P. (1979): "Cratere neoattico: tipo Borghese", en Giuliano, A. (ed.), Museo Nazionale Romano I. Le sculture 1: 257-260. Roma, De Luca.

Robert, R. (2003): "Fragment de fût de candélabre", en Terrer, D.; Lauxerois, R.; Robert, R.;
Gaggadis-Robin, V.; Hermary, A.; Jockey, Ph. y Lavagne, H.: Nouvel Espérandieu. Recueil général des sculptures sur pierre de la Gaule I. Vienne (Isère): 186. París, Académie des Inscriptions et Belles-Lettres.

Ruiz, J. C. (2019): "Dos estatuillas de erotes halladas en 1868 en Tarragona". Butlletí Arqueològic 41: 143-166.

Ruiz, J. C. (2020): "Las esculturas halladas en 19251930 en el área del foro local de Tarraco", en J. M. Noguera y L. Ruiz (eds.), Escultura Romana en Hispania IX: 191-206. Yecla, Ayuntamiento de Yecla.

Ruiz, J. C. (en prensa): "Nuevos relieves arquitectónicos con decoración vegetal procedentes del área del templo al divus Augustus en Tarraco". Revista d'Arqueologia de Ponent 30.

Serra, J. (1960): Santa Tecla la Vieja. Tarragona, Sugrañes.

Sinn, Fr. (1987): Stadtrömische Marmorurnen. Mainz am Rhein, Von Zabern.

TED'A (1989): "El foro provincial de Tarraco, un complejo arquitectónico de época flavia”. Archivo Español de Arqueología 62: 141-191.

Ungaro, L. (2017): "Simboli e immagini del trionfo in marmo: 'barbari', romani e congeries armorum nel Foro di Traiano", en C. Parisi Presicce, M. Milella, S. Pastor y L. Ungaro (eds.), Traiano. Costruire l'Impero, Creare l'Europa: 291-296. Roma, De Luca.

Vargas, S. (2018): "La techumbre marmórea del Traianeum de Italica", en J. Beltrán, M. L. Loza y E. Ontiveros (coords.), Marmora Baeticae. Usos de materiales pétreos en la Bética romana. Estudios arqueológicos y análisis arqueométricos: 215-222. Sevilla, Universidad de Sevilla.

Villaronga, L. y Benages, J. (2011): Ancient Coinage of the Iberian Peninsula. Les monedes de l'etat antiga a la Península Ibèrica: Greek, Punic, Iberian, Roman. Barcelona, Societat Catalana d'Estudis Numismàtics - Institut d'Estudis Catalans. 
